\title{
Copper, Zinc, and Lead Mineral Prospectivity Mapping in the North of Tafresh, Markazi Province, Central Iran, Using the AHP-OWA Method
}

\author{
Masoumeh Mahbouby Niyeh¹, Alireza Jafarirad1, Jalal Karami², Saeed Jabbari Bokani ${ }^{3}$ \\ ${ }^{1}$ Department of Geology, Islamic Azad University, Science and Research Branch, Tehran, Iran \\ ${ }^{2}$ Department of Geography, Tarbiat Modares University, Tehran, Iran \\ ${ }^{3}$ Department of Geomatics, Geological Survey of Iran (GSI), Tehran, Iran \\ Email:mmahbouby@ymail.com, alirad@yahoo.com, jl.karami@gmail.com, saeed.jr@gmail.com
}

How to cite this paper: Niyeh, M.M., Jafarirad, A., Karami, J. and Bokani, S.J. (2017) Copper, Zinc, and Lead Mineral Prospectivity Mapping in the North of Tafresh, Markazi Province, Central Iran, Using the AHP-OWA Method. Open Journal of Geology, 7, 533-558.

https://doi.org/10.4236/ojg.2017.74037

Received: November 30, 2016

Accepted: April 27, 2017

Published: April 30, 2017

Copyright $\odot 2017$ by authors and Scientific Research Publishing Inc. This work is licensed under the Creative Commons Attribution International License (CC BY 4.0).

http://creativecommons.org/licenses/by/4.0/

\begin{abstract}
The reason of this research is to identify the favorable areas for copper, zinc, and lead mineralization in the western part of the 1:100,000 Tafresh geological Sheet in the Urmia-Dokhtar structural zone of Iran. Effective data layers for mineralization, such as geology, geochemistry, structures, and satellite images, were analyzed and then integrated using the AHP-OWA method to identify favorable areas. Geochemical stream samples were analyzed by univariate, multivariate, and classical statistical methods and revealed the first, second, and third class anomalies for copper, zinc, and lead in the study region. Detection of hydrothermal alteration zones by Advanced Spaceborne Thermal Emission and Reflection Radiometer (ASTER) satellite imagery in various algorithms, such as Relative absorption Band Depth (RBD), Minimum Noise Fraction (MNF), and Least Square Fit (LS-Fit), shows that argillic, phyllic, propylitic, and iron oxide alterations develop around the faults in the area under study. The favorable areas for copper, zinc, and lead mineralization have been identified by a combination of evidence maps of lithology, faults, dikes, geochemistry, and alteration data layers. Field observations in the area under study have confirmed the results.
\end{abstract}

\section{Keywords}

Mineral Prospectivity, Tafresh, Urmia-Dokhtar, Stream Sample, Remote Sensing, AHP-OWA

\section{Introduction}

Stream sediment geochemistry is a useful technique for identifying important 
deposits [1]. The aim of this research is to examine the efficacy of stream sediment geochemical survey for locating copper, zinc, and lead in the area under study.

The elemental correlations were calculated by applying the Pearson correlation method, factor analysis, and classical method to elemental concentration data to study copper, zinc, and lead paragenesis and to define geochemical anomaly thresholds to find copper, zinc, and lead prospects in the region.

The use of Advanced Spaceborne Thermal Emission and Reflection Radiometer (ASTER) satellite imagery in mineral exploration has developed in recent years [2]. In this research, hydrothermal alteration zones were detected using ASTER data in different algorithms: Relative absorption Band Depth (RBD), Minimum Noise Fraction (MNF), and Least Squares Fit (LS-Fit).

Geospatial data, such as geochemical, geological, structural, and remotely sensed data, are particularly suitable to extract information that is useful in mineral prospecting [3]-[9].

The application of the analytic hierarchy process (AHP) method is useful for binary index overlay modeling, as well as for multi-class index overlay modeling and fuzzy logic modeling [10].

The ordered weighted averaging (OWA) model provides a continuous fuzzy between fuzzy intersection (AND) and union (OR) [11] [12]. The AHP is used to deduce attribute weights and the OWA operator function is used to produce a wide variety of decisions [13]. Combining information layers with AHP-OWA is an effective method to produce mineral potential mapping in the region. Field observations have confirmed the results.

\section{Geology Setting}

The area under study is situated between $50^{\circ} \mathrm{E}$ to $50^{\circ} 15^{\prime} \mathrm{E}$ and $34^{\circ} 30^{\prime} \mathrm{N}$ to $35^{\circ} \mathrm{N}$ in the Urmia-Dokhtar structural zone of Iran [14]. The Urumieh-Dokhtar magmatic belt (UDMB) hosts porphyry copper deposits [15]-[21].

The oldest outcrops in the region are the Middle Triassic sandy shale rocks (the Nayband formation). Eocene volcanic rocks (mostly tuff and andesitic rocks with limestone interlayers compositions) with a thickness of approximately 3000 meters cover most of the area. Intrusive tonalite to granodiorite has been injected into Eocene volcanic rocks and has metamorphosed in greenschist facies [22]. The Lower Red, Qom, and Upper Red formations, with sedimentary rocks, outcrop in the northern parts of the area. Eocene dykes with micro-diorite and andesitic and Neogene dykes with basaltic-andesitic compositions have greatly spread in the area under study (Figure 1).

\section{Materials and Methods}

520 stream sediment samples gathered and analyzed by the Geological Survey of Iran (GSI) in 2006. The samples were chemically analyzed by ICP-MS for 19 elements (Ag, As, $\mathrm{Au}, \mathrm{Ba}, \mathrm{Bi}, \mathrm{Cd}, \mathrm{Co}, \mathrm{Cr}, \mathrm{Cu}, \mathrm{Hg}, \mathrm{Ni}, \mathrm{Pb}, \mathrm{Sb}, \mathrm{Sc}, \mathrm{Sn}, \mathrm{Sr}, \mathrm{V}, \mathrm{W}, \mathrm{Y}$, and $\mathrm{Zn}$ ), with detection limit of $0.05 \mathrm{ppm}$ for copper, zinc, and lead. Thompson 


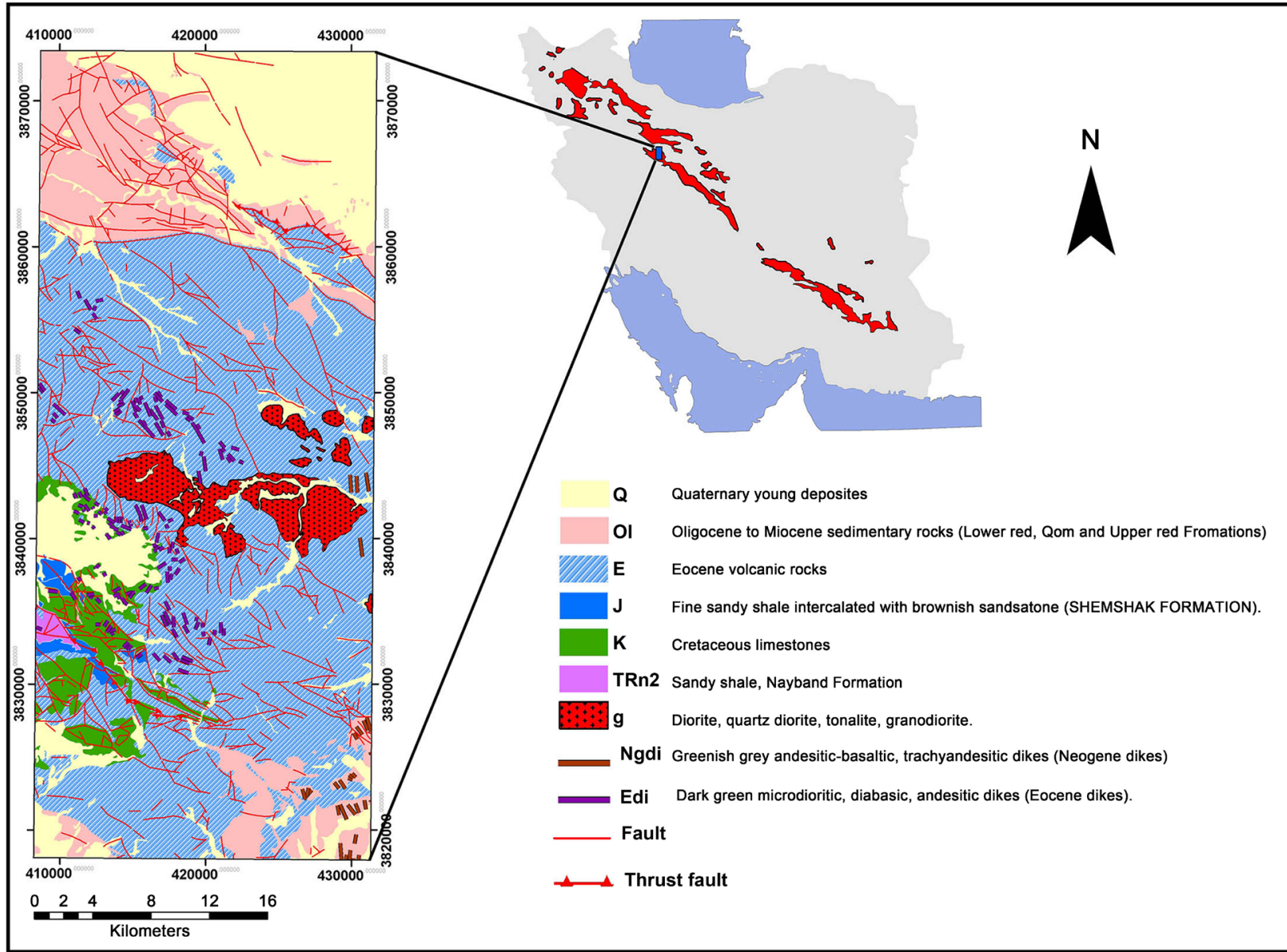

Figure 1. The simple geology map of study area and its location in UDMB.

control diagrams and relative error calculations were used to control the accuracy of the analysis.

The elemental correlation coefficients and paragenesis were found by applying bivariate and multivariate statistical analysis [23] [24] to the geochemical data using SPSS 18 statistical software package. Bivariate matrix of correlation coefficients was calculated by the Pearson correlation method [25].

Hydrothermally altered minerals and lithological mapping have been successfully recognized through remote sensing instruments for mineral exploration [26] [27] [28] [29] [30]; therefore, in this research, the ASTER image has been used and data analyses were done by ENVI 4.2 software. This work mainly focused on mapping of hydrothermal alterations in the volcano-plutonic belt; therefore, the sedimentary rocks and quaternary deposits outside the volcanic and plutonic rocks were masked. Evidence maps were produced from the data layers using ArcGIS 9.3 software and potential maps were generated by the AHP-OWA method using IDRISI 17.0 software. After data processing, the validity of the results was confirmed by field work.

\section{Geochemical Data}

In this study, Pearson correlation confirmed a strong correlation between $\mathrm{Pb}$ 
Table 1. Pearson correlation coefficients for chemical analyses of samples from the area under study.

\begin{tabular}{|c|c|c|c|c|c|c|c|c|c|c|c|c|c|c|c|c|c|c|c|}
\hline & $\mathrm{Ag}$ & As & $\mathrm{Ba}$ & $\mathrm{Bi}$ & $\mathrm{Cd}$ & Co & $\mathrm{Cr}$ & $\mathrm{Cu}$ & $\mathrm{Hg}$ & $\mathrm{Ni}$ & $\mathrm{Pb}$ & $\mathrm{Sb}$ & Sc & Sn & $\mathrm{Sr}$ & V & W & $\mathrm{Y}$ & $\mathrm{Zn}$ \\
\hline $\mathrm{Ag}$ & 1 & & & & & & & & & & & & & & & & & & \\
\hline $\mathrm{Ba}$ & 0.933 & 0.851 & 1 & & & & & & & & & & & & & & & & \\
\hline $\mathrm{Bi}$ & -0.242 & -0.422 & -0.213 & 1 & & & & & & & & & & & & & & & \\
\hline $\mathrm{Cd}$ & -0.671 & -0.602 & -0.811 & 0.135 & 1 & & & & & & & & & & & & & & \\
\hline Co & -0.645 & -0.599 & -0.773 & 0.168 & 0.931 & 1 & & & & & & & & & & & & & \\
\hline $\mathrm{Cr}$ & 0.207 & 0.398 & 0.188 & -0.687 & -0.182 & -0.209 & 1 & & & & & & & & & & & & \\
\hline $\mathrm{Cu}$ & -0.273 & -0.119 & -0.454 & -0.347 & 0.637 & 0.553 & 0.441 & 1 & & & & & & & & & & & \\
\hline $\begin{array}{c}\mathrm{H} \\
\mathrm{g}\end{array}$ & -0.334 & -0.278 & -0.513 & 0.078 & 0.706 & 0.671 & -0.093 & 0.617 & 1 & & & & & & & & & & \\
\hline $\mathrm{Ni}$ & -0.189 & 0.021 & -0.260 & -0.558 & 0.254 & 0.187 & 0.785 & 0.698 & 0.167 & 1 & & & & & & & & & \\
\hline $\mathrm{Pb}$ & 0.850 & 0.788 & 0.931 & -0.225 & -0.847 & -0.803 & 0.252 & -0.494 & -0.626 & -0.167 & 1 & & & & & & & & \\
\hline $\mathrm{Sb}$ & -0.466 & -0.261 & -0.587 & 0.197 & 0.835 & 0.763 & -0.127 & 0.543 & 0.642 & 0.204 & -0.624 & 1 & & & & & & & \\
\hline Sc & 0.487 & 0.581 & 0.536 & -0.624 & -0.620 & -0.608 & 0.794 & 0.011 & -0.435 & 0.447 & 0.596 & -0.509 & 1 & & & & & & \\
\hline Sn & 0.570 & 0.424 & 0.716 & 0.238 & -0.916 & -0.826 & -0.109 & -0.764 & -0.640 & -0.500 & 0.729 & -0.746 & 0.361 & 1 & & & & & \\
\hline $\mathrm{Sr}$ & -0.679 & -0.618 & -0.821 & 0.183 & 0.958 & 0.904 & -0.180 & 0.641 & 0.699 & 0.253 & -0.848 & 0.801 & -0.601 & -0.852 & 1 & & & & \\
\hline V & 0.523 & 0.646 & 0.558 & -0.558 & -0.564 & -0.552 & 0.781 & 0.038 & -0.379 & 0.433 & 0.606 & -0.405 & 0.930 & 0.324 & -0.559 & 1 & & & \\
\hline $\mathrm{W}$ & 0.331 & 0.449 & 0.216 & 0.021 & 0.139 & 0.077 & 0.084 & 0.245 & 0.326 & 0.072 & 0.139 & 0.408 & -0.058 & -0.141 & 0.097 & 0.064 & 1 & & \\
\hline $\mathrm{Y}$ & -0.635 & -0.563 & -0.779 & 0.171 & 0.993 & 0.920 & -0.185 & 0.633 & 0.713 & 0.253 & -0.814 & 0.862 & -0.630 & -0.906 & 0.948 & -0.557 & 0.209 & 1 & \\
\hline
\end{tabular}

and $\mathrm{As}, \mathrm{Pb}$ and $\mathrm{Ag}$, and $\mathrm{Pb}$ and $\mathrm{Ba}$ (Table 1). Reduction of variables was accomplished by factor analysis, and 19 elements were classified into three factors. Table 2 shows that:

Factor 1 (43.64\% of variance) is strongly positively correlated to $\mathrm{Y}, \mathrm{Cd}, \mathrm{Sr}, \mathrm{Sb}$, $\mathrm{Co}, \mathrm{Hg}$, and $\mathrm{Cu}$ and negatively correlated to $\mathrm{Pb}$ and $\mathrm{Sn}$, with very weak correlation to $\mathrm{Zn}$.

Factor 2 (21.85\% of variance) is strongly positively correlated to $\mathrm{Cr}, \mathrm{Ni}, \mathrm{Sc}$, and $\mathrm{V}$ and negatively correlated to Bi.

Factor 3 (19.15\% of variance) is strongly positively correlated to As, Ag, W, and $\mathrm{Ba}$, negatively correlated to $\mathrm{Zn}$, and weakly correlated to $\mathrm{Pb}$. Statistically significant correlation was not found between $\mathrm{Pb}$ and $\mathrm{Zn}$ in the area under study.

The catchment basins produced by a digital elevation model (DEM) in ARCGIS software (Figure 2).

We separated the background and anomaly populations by classical statistics method [31] as three classes for zinc, lead, and copper in the area under study (Figure 3). $\bar{X}+S$ is normally considered as the threshold value, $\bar{X}+2 S$ as a possible anomaly, and $\bar{X}+3 S$ as a probable anomaly.

\section{Remote Sensing}

Recent years, remote sensing images are used to identify hydrothermally altered 
Table 2. Varimax rotated factor matrix for 19 elements in 520 stream sediment samples of the area under study.

\begin{tabular}{|c|c|c|c|}
\hline \multirow{2}{*}{ Elements } & \multicolumn{3}{|c|}{ Rotated Component Matrix } \\
\hline & Factor 1 & Factor 2 & Factor 3 \\
\hline $\mathrm{Y}$ & 0.946 & -0.138 & -0.228 \\
\hline $\mathrm{Cd}$ & 0.936 & -0.114 & -0.284 \\
\hline $\mathrm{Sr}$ & 0.904 & -0.117 & -0.316 \\
\hline $\mathrm{Sb}$ & 0.88 & -0.15 & 0.025 \\
\hline Co & 0.866 & -0.152 & -0.305 \\
\hline $\mathrm{Hg}$ & 0.823 & -0.079 & 0.101 \\
\hline $\mathrm{Cu}$ & 0.769 & 0.515 & 0.025 \\
\hline Sn & -0.904 & -0.218 & 0.217 \\
\hline $\mathrm{Pb}$ & -0.738 & 0.149 & 0.564 \\
\hline $\mathrm{Cr}$ & -0.034 & 0.936 & 0.121 \\
\hline $\mathrm{Ni}$ & 0.351 & 0.841 & -0.137 \\
\hline Sc & -0.502 & 0.789 & 0.205 \\
\hline $\mathrm{V}$ & -0.426 & 0.749 & 0.304 \\
\hline $\mathrm{Bi}$ & 0.018 & -0.819 & -0.179 \\
\hline As & -0.354 & 0.305 & 0.835 \\
\hline $\mathrm{Ag}$ & -0.487 & 0.112 & 0.806 \\
\hline $\mathrm{W}$ & 0.396 & -0.067 & 0.763 \\
\hline $\mathrm{Ba}$ & -0.67 & 0.083 & 0.699 \\
\hline $\mathrm{Zn}$ & 0.151 & -0.405 & -0.567 \\
\hline Proportion of total variance $\%$ & 43.645 & 21.849 & 19.153 \\
\hline
\end{tabular}

rocks and to produce the maps of geology, faults, and fractures [32]. In this study, an ASTER image has been used to detect alteration zones.

\subsection{ASTER Data}

ASTER is one of the recently designed generations of medium resolution multispectral satellite remote systems that are reported to have substantial applications in geological mapping [2]. ASTER has 14 bands: Three visible and near infrared radiation ( 0.52 to $0.86 \mu \mathrm{m})$ (VNIR, $15 \mathrm{~m})$; six shortwave infrared radiation $(1.6$ to $2.43 \mu \mathrm{m}$ ) (SWIR, $30 \mathrm{~m}$ ) and five thermal infrared radiations ( 8.125 to $11.65 \mu \mathrm{m}$ ) (TIR, 90m) [33] [34]. Many investigations have been carried out using ASTER [35] [36]. The ASTER spectral properties were used to map iron oxide, argillic, phyllic, and propylitic alteration zones by RBD, MNF, and LS-Fit methods in the present study.

\subsection{Image Processing Methods on ASTER Imagery}

\subsubsection{Relative Absorption Band Depth (RBD)}

An RBD image is produced by dividing the sum of the maximum reflectance 


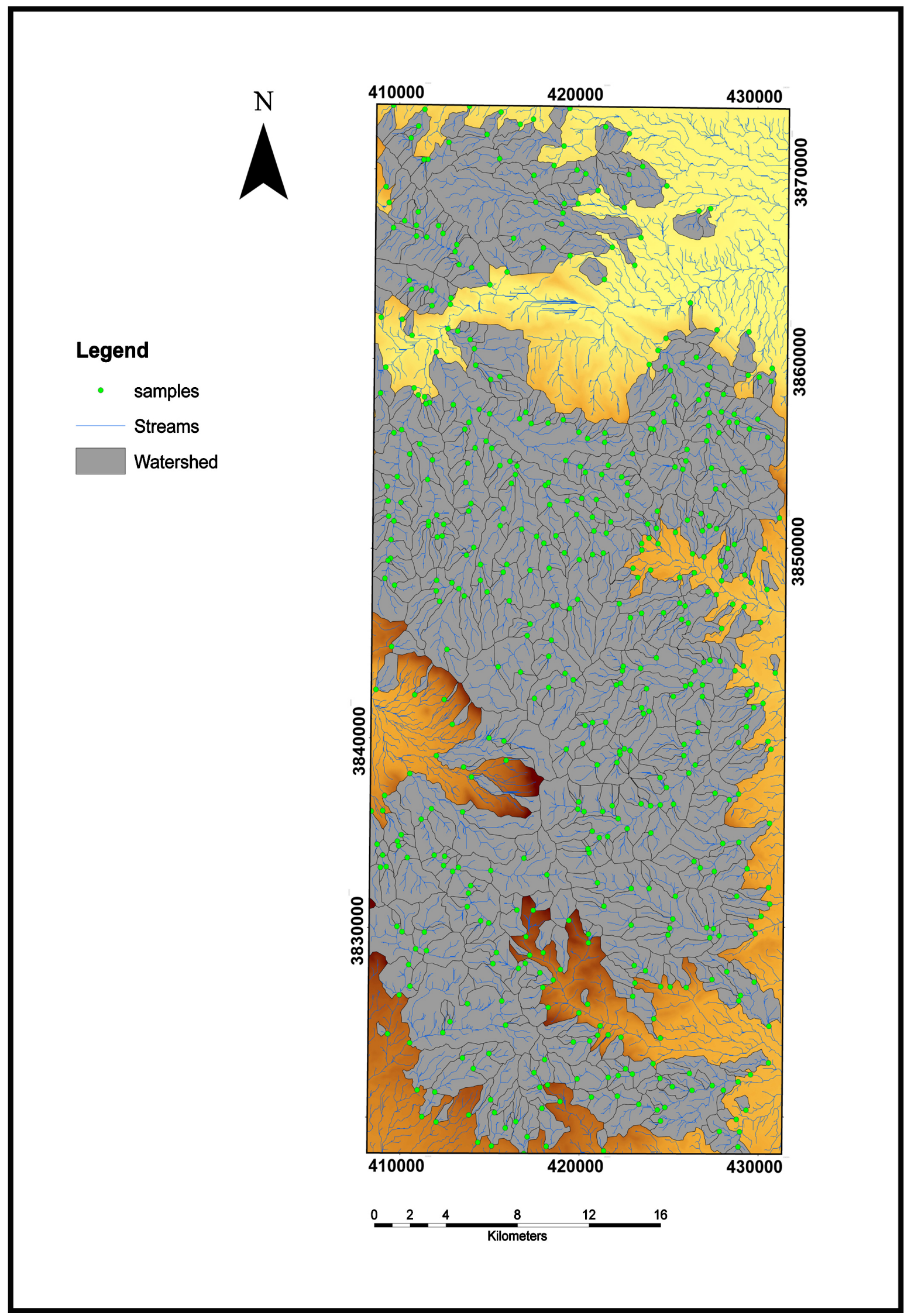

Figure 2. Locations of 520 stream sediment samples and their watersheds in the area under study. 

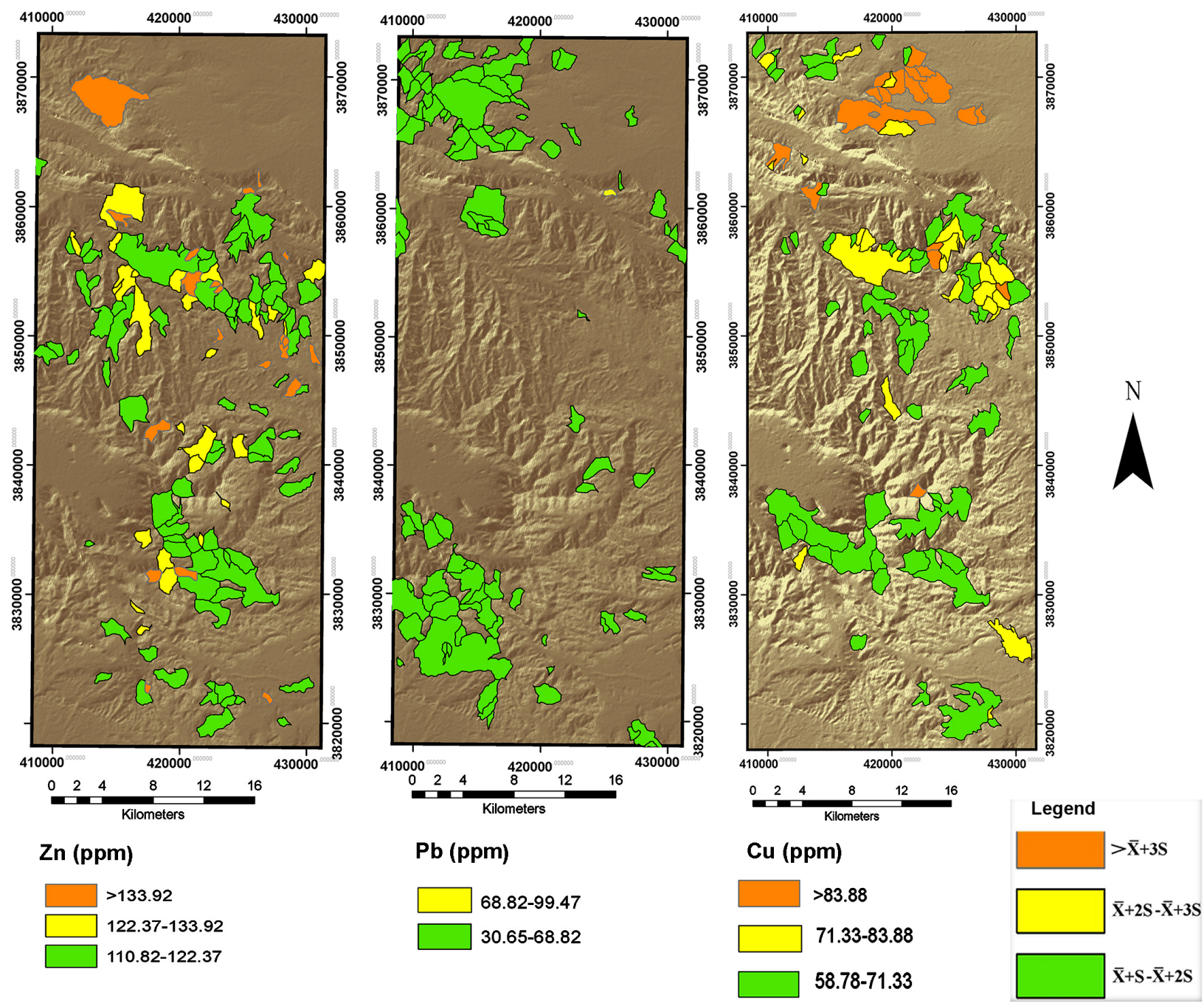

Figure 3. Geochemical anomaly maps of $\mathrm{Zn}, \mathrm{Pb}$ and $\mathrm{Cu}$ in the area under study.

bands to maximum absorption band [37] [38]. Phyllic alteration with abundance of illite and sericite has strong absorption at $2.20 \mu \mathrm{m}$ (ASTER band 6) [39]. The argillic alteration (kaolinite and alunite), has strong absorption at $2.17 \mu \mathrm{m}$ (ASTER band 5) [40], and propylitic alteration dominated by chlorite, epidote and carbonates, has strong absorption in the $2.335 \mu \mathrm{m}$ (ASTER band 8) (Figure 4). Table 3 shows the common band combinations that were used to create the maps of argillic, phyllic, and propylitic alteration zones in the present study (Figure 5).

\subsubsection{Minimum Noise Fraction (MNF)}

Because spectral anomalies are related to hydrothermal mineralization, this method is more interest to exploration geologists [41] [42] [43]. MNF Bands 7, 6, 4, and 3 have been used for, propylitic argillic, phyllic, and iron oxide alterations in the present study (Figure 6).

\subsubsection{Least Squares Fitting (LS-Fit)}

The superiority of this method compared to other methods is the reduction of 
noise in images [44]. To identify alteration zones, visible and near-infrared (VNIR) bands used as the input bands and band 1 as the modeled band for Iron oxide, band 4 for argillic, band 6 for phyllic and band 9 for propylitic (Figure 7).

\section{Generation of Information Layers for Study Area}

\subsection{Fault Layer}

Mineralization is more probable along a fault; therefore, faults are considered as one of the most significant elements in mineralization [45]. The presence of these geological features indicates enhanced structural permeability of the rocks in the subsurface, which facilitates upward migration of ground water that has come in contact with and has leached substances from buried deposits. These arguments suggest that the significance of multi-element stream sediment anomalies in sample catchment basins can be screened for or examined further using fault density as a factor [46]. In this research, the map of fault distributions

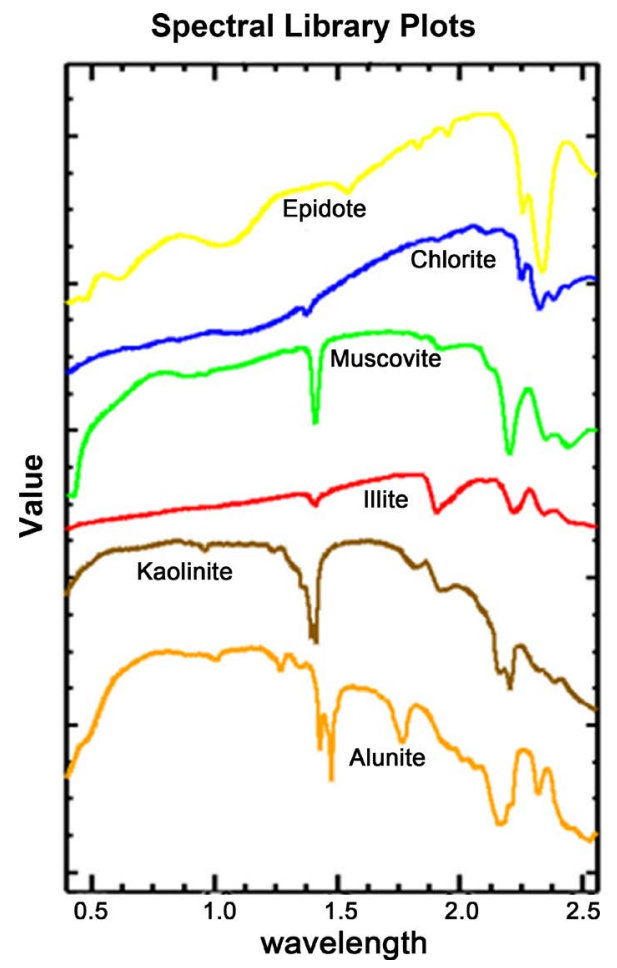

Figure 4. Laboratory spectra of muscovite, kaolinite, alunite, epidote, calcite, and chlorite resampled to ASTER band passes.

Table 3. Common ratio and band combinations for mapping alteration zones in the area under study.

\begin{tabular}{cccc}
\hline Feature & band or ratio & Comments & Reference \\
\hline Sericite/muscovite/illite/smectite & $(5+7) / 6$ & Phyllic alteration & $\begin{array}{c}\text { Rowan (USGS); } \\
\text { Hewson (CSIRO) }\end{array}$ \\
Alunite/kaolinite/pyrophyllite & $(4+6) / 5$ & Argillic altration & Rowan (USGS) \\
Carbonate/chlorite/epidote & $(7+9) / 8$ & Propylitic & Rowan \\
\hline
\end{tabular}



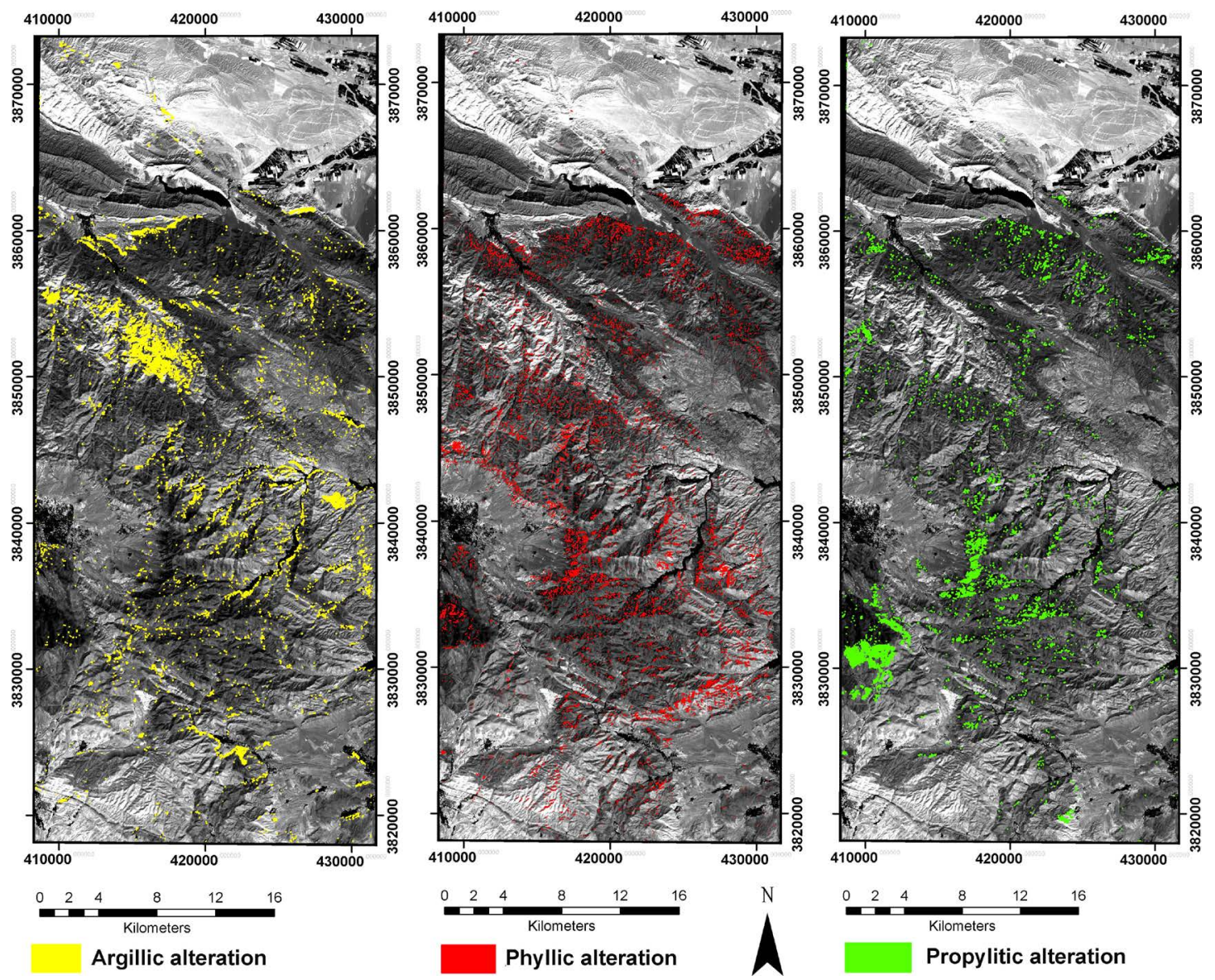

Figure 5. Argillic, phyllic, propylitic and iron oxide images were prepared by RBD method.

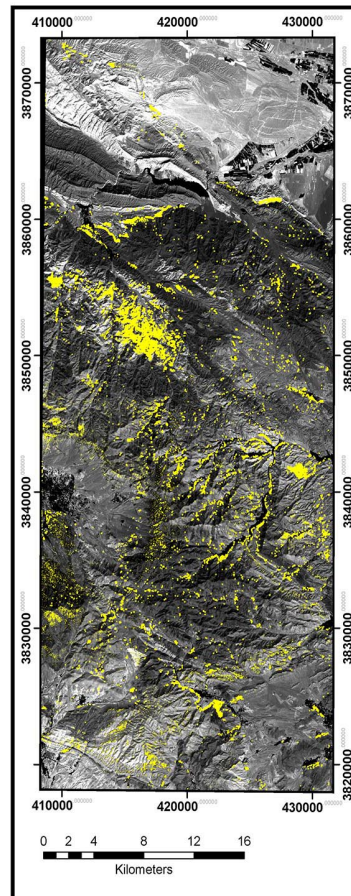

Argillic alteration

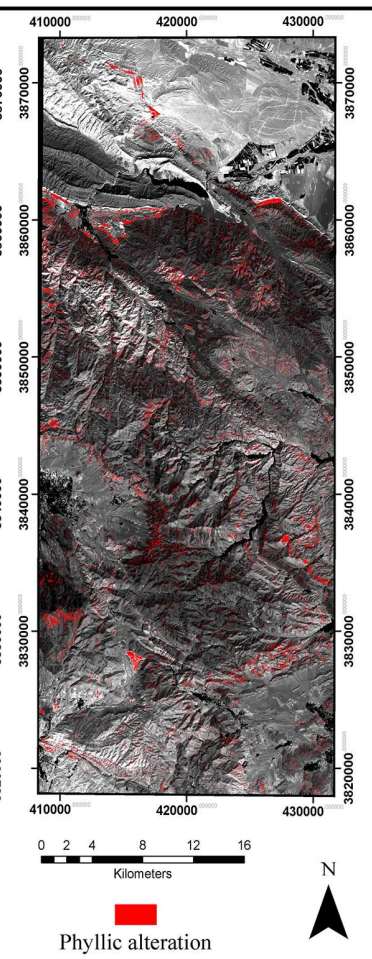

Phyllic alteration

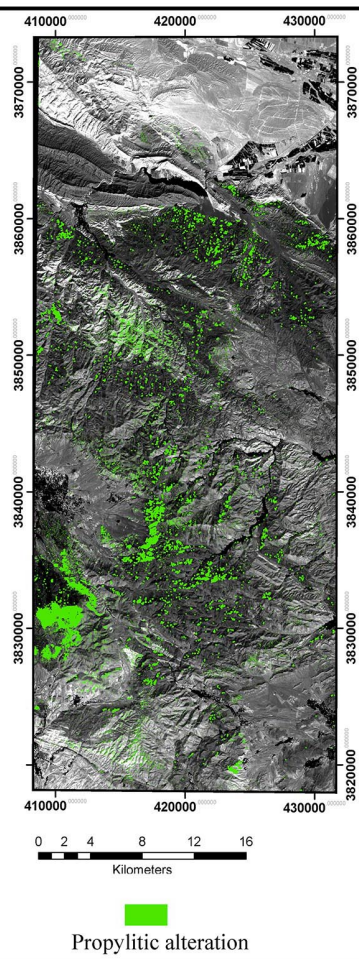

Propylitic alteration

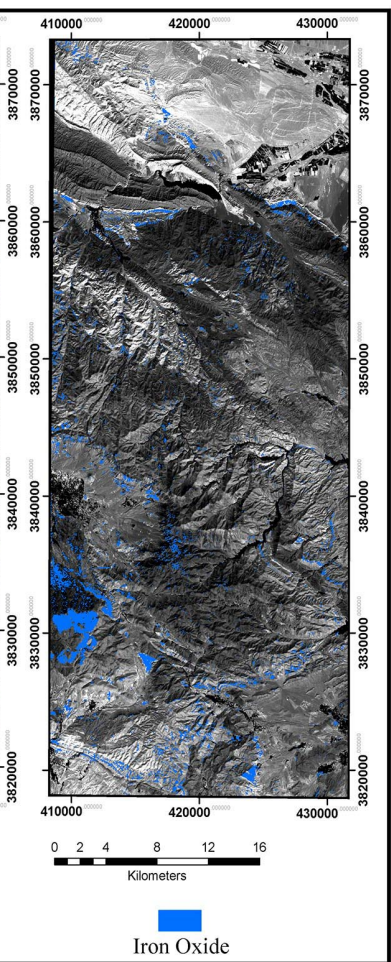

Iron Oxide

Figure 6. The argillic, phyllic, propylitic and iron oxide images were prepared by MNF method. 

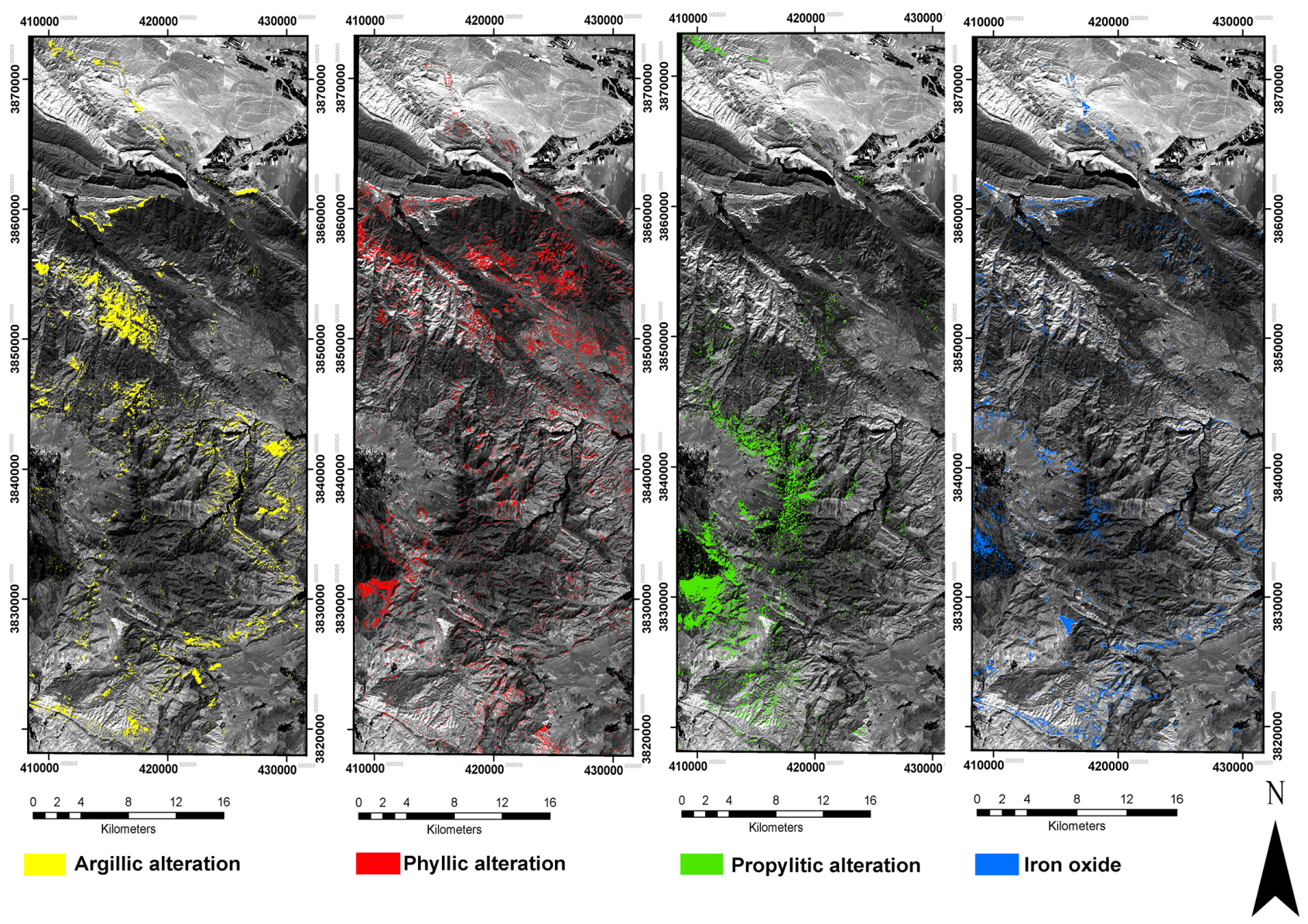

Figure 7. Argillic, phyllic, propylitic and iron oxide images were prepared by Ls-fit method.

was derived from the 1:100,000 geological map of Tafresh (Figure 8). The fault map was used to create a fault density map (Figure 8) and reclassified into ten classes in ArcGIS. The highest number had the strongest preference (Figure 8).

\subsection{Lithology Layer}

This layer was derived from the 1:100,000 geological map of Taferesh. The most important component in this layer is the volcanic rocks (i.e., andesitic basalt, basaltic andesite, and andesite). The units of the geologic map were reclassified into ten classes according to their mineralization ability (Figure 9). The sedimentary rocks and younger geological units, such as the older and younger terraces, were assigned the smallest value.

\subsection{Dike Layer}

The abundance of dikes interpreted from geological map in the area under study was applied to create separate linear structural features. A dike evidence map was generated by reclassifying the dike buffer map (Figure 10) into nine classes.

\subsection{Alteration Layer}

The present research used different algorithms to excavate the most common hydrothermal alterations, namely iron oxide, phyllic, argillic, and propylitic, by 
processing ASTER images. The alteration evidence map was produced by combining the results from different algorithms and reclassifying to ten classes (Figure 11).

\subsection{Geochemical Layer}

The geochemical evidence map for three elements, zinc, lead, and copper, was produced after providing geochemical maps, combining them, and reclassifying to ten classes in ArcGIS software (Figure 12).
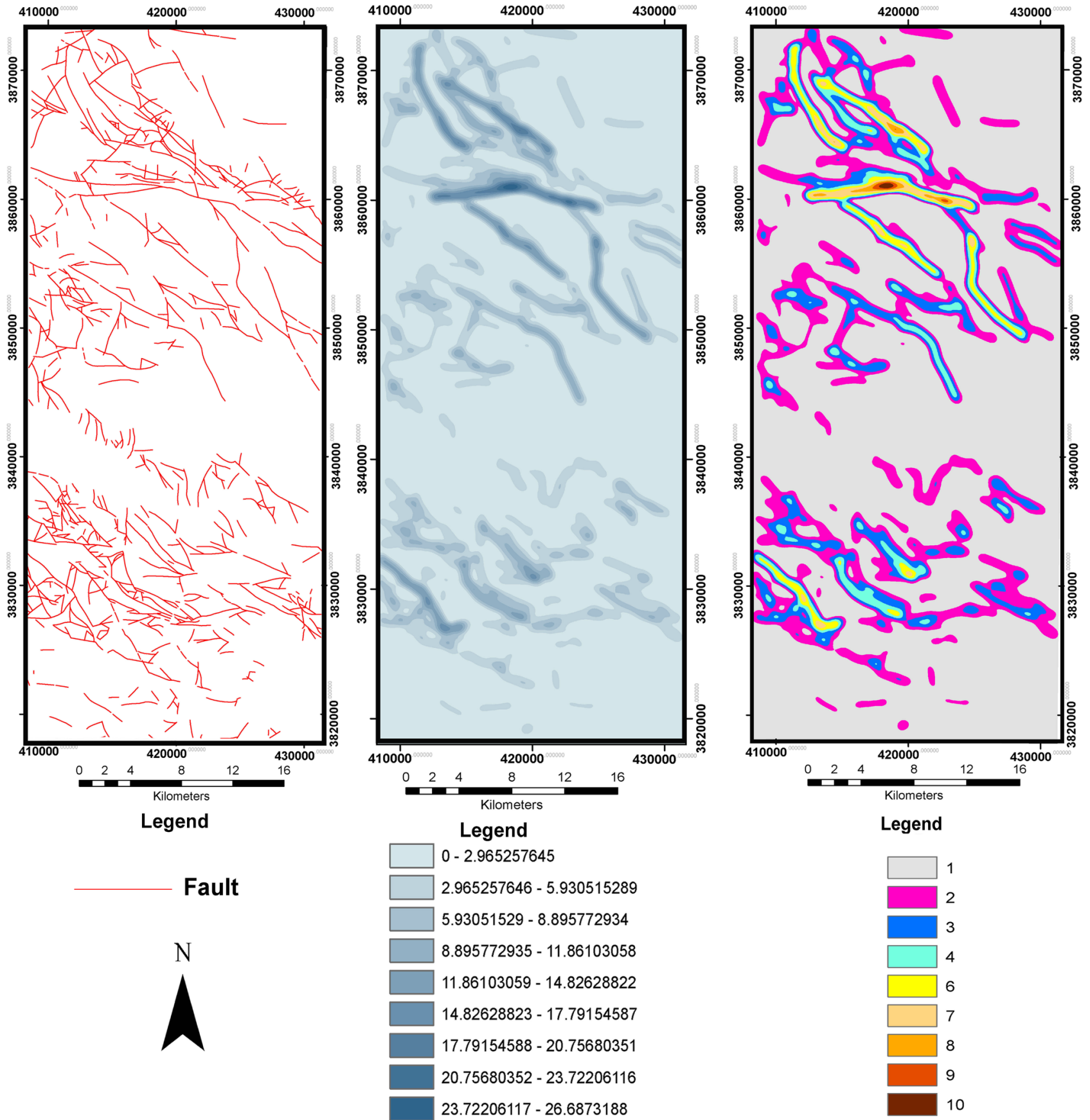

Figure 8. The fault layer of the area under study: fault map (left), fault density map (center) and fault density reclassified map (right). 


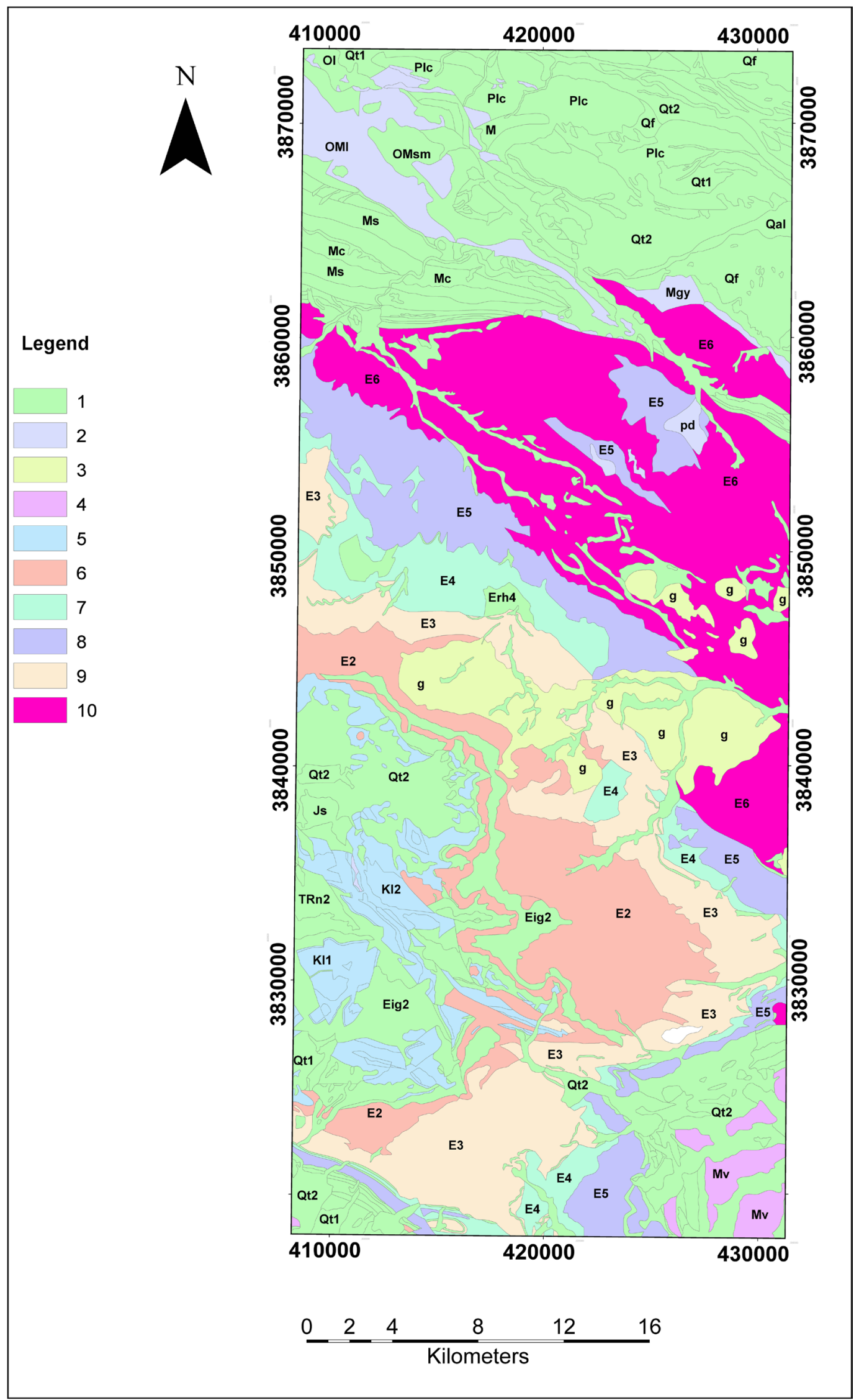

Figure 9. The lithology layer of the area under study. 

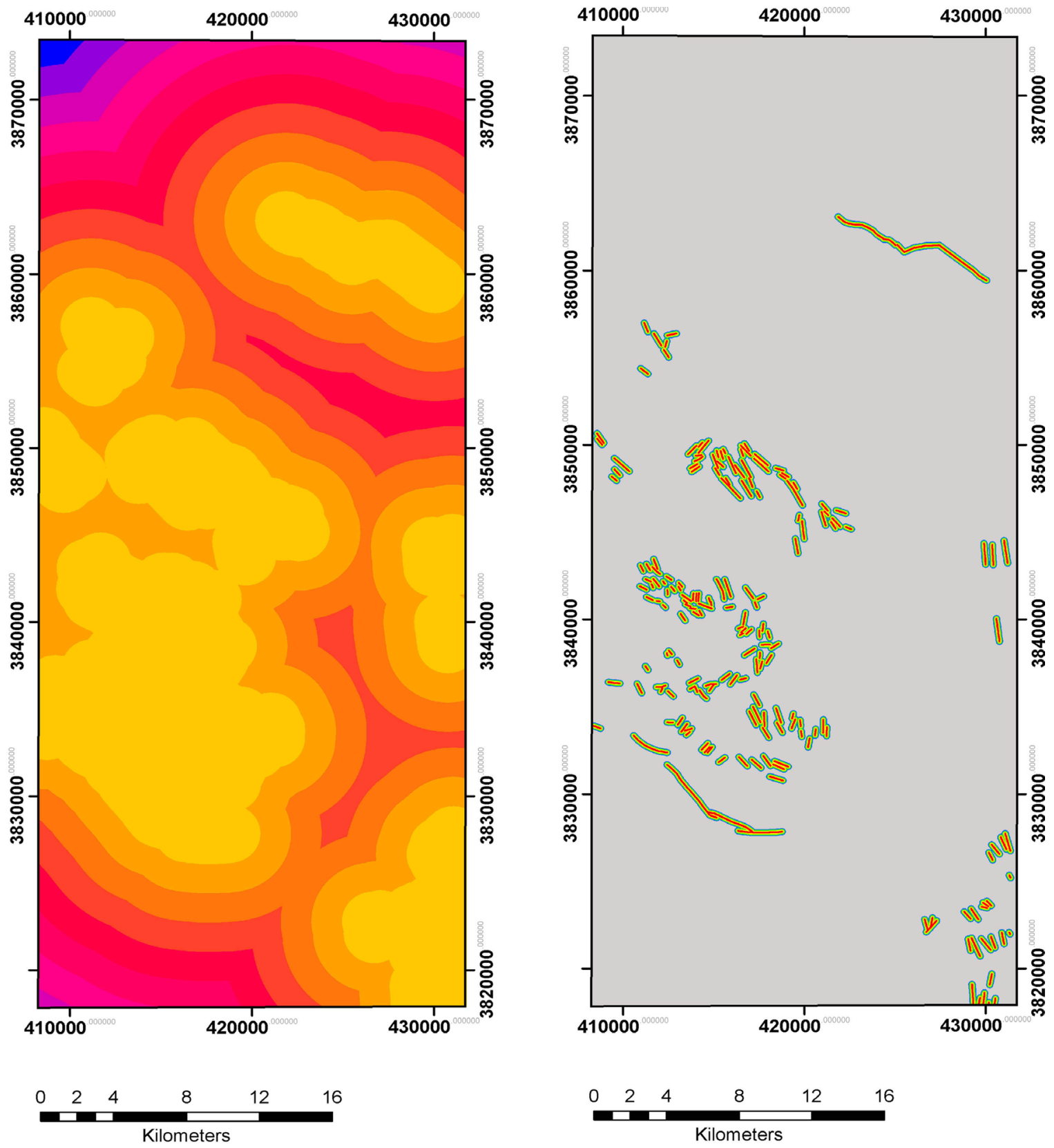

\section{Legend}

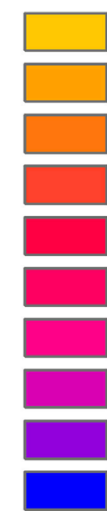
$0-1681.478516$
1681.478517 - 3362.957031
3362.957032 - 5044.435547
$5044.435548-6725.914063$
6725.914064 - 8407.392578
$8407.392579-10,088.87109$
$10,088.8711-11,770.34961$
$11,770.34962-13,451.82813$
$13,451.82814-15,133.30664$
$15,133.30665$ - 16,814.78516

\section{Legend}

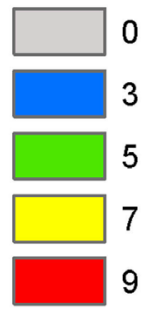

Figure 10. The dike layer of the area under study: Dike buffer map (left) and dike buffer reclassified map (right). 
Legend

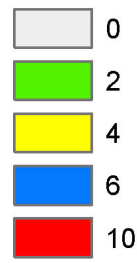

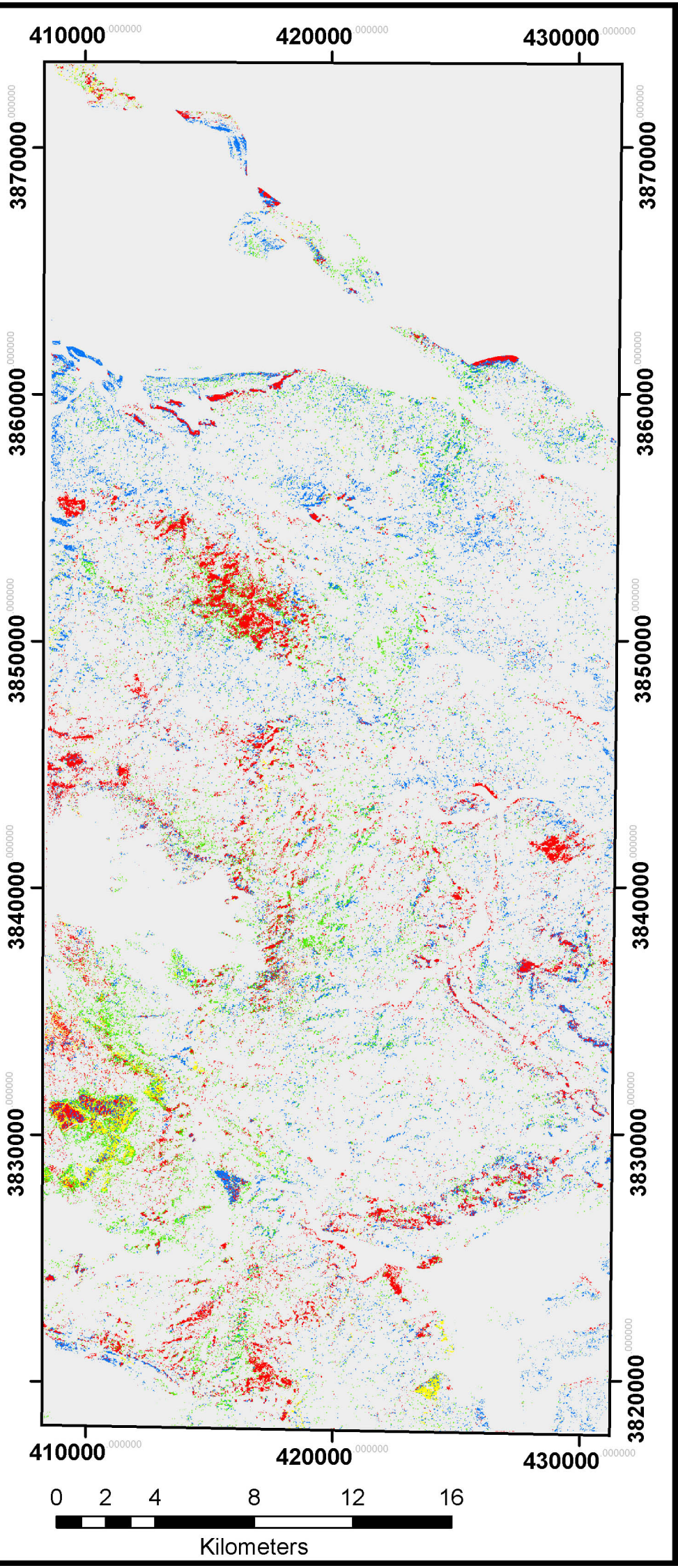

Figure 11 . The alteration layer of the area under study. 


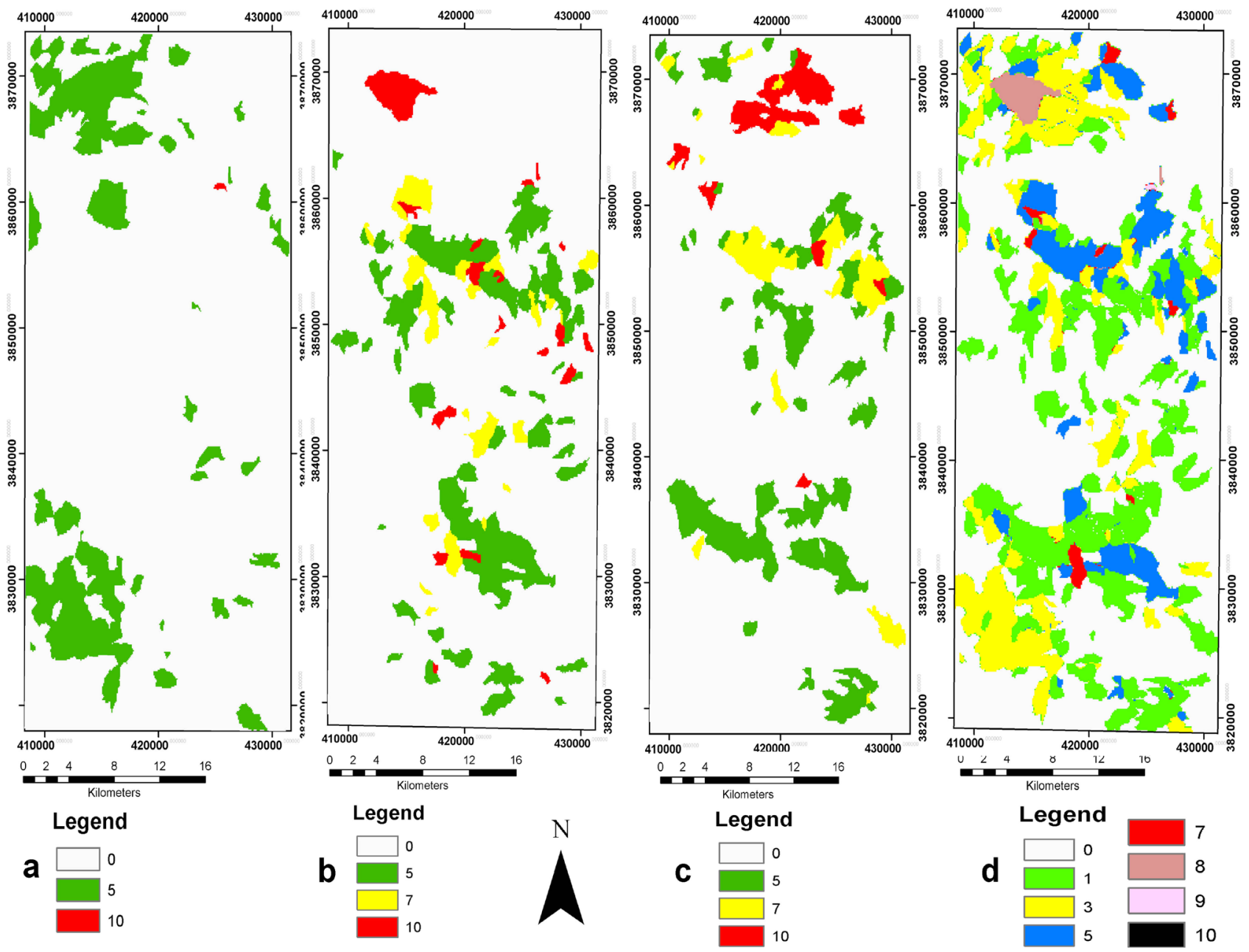

Figure 12. (a) Pb geochemical layer. (b) Zn geochemical layer. (c) Cu geochemical layer. (d) The geochemical evidence layer of the area under study

\section{Integration of the Layers and Mapping the Potential Area}

The mineral potential map of the area under study multiple layers (lithology, fault, dike, alteration, and geochemistry) were produced by combining them by the AHP-OWA method.

\subsection{The Analytical Hierarchy Process (AHP) Method}

\subsubsection{The AHP Hierarchy}

The hierarchical diagram has four main levels: goals, objectives, attributes, and alternatives [47]. The hierarchical diagram was produced for information layers of the area under study (Figure 13).

\subsubsection{Pairwise Comparisons}

In the AHP method, the pairwise comparison is the fundamental measurement mode [47]. Table 4 shows the values from 1 to 9 that were used to rate the relative preferences for two elements of the hierarchy in the area under study. The pairwise comparison matrix and calculated weights for the objectives of the present study area were calculated using IDRISI software (Table 5). 


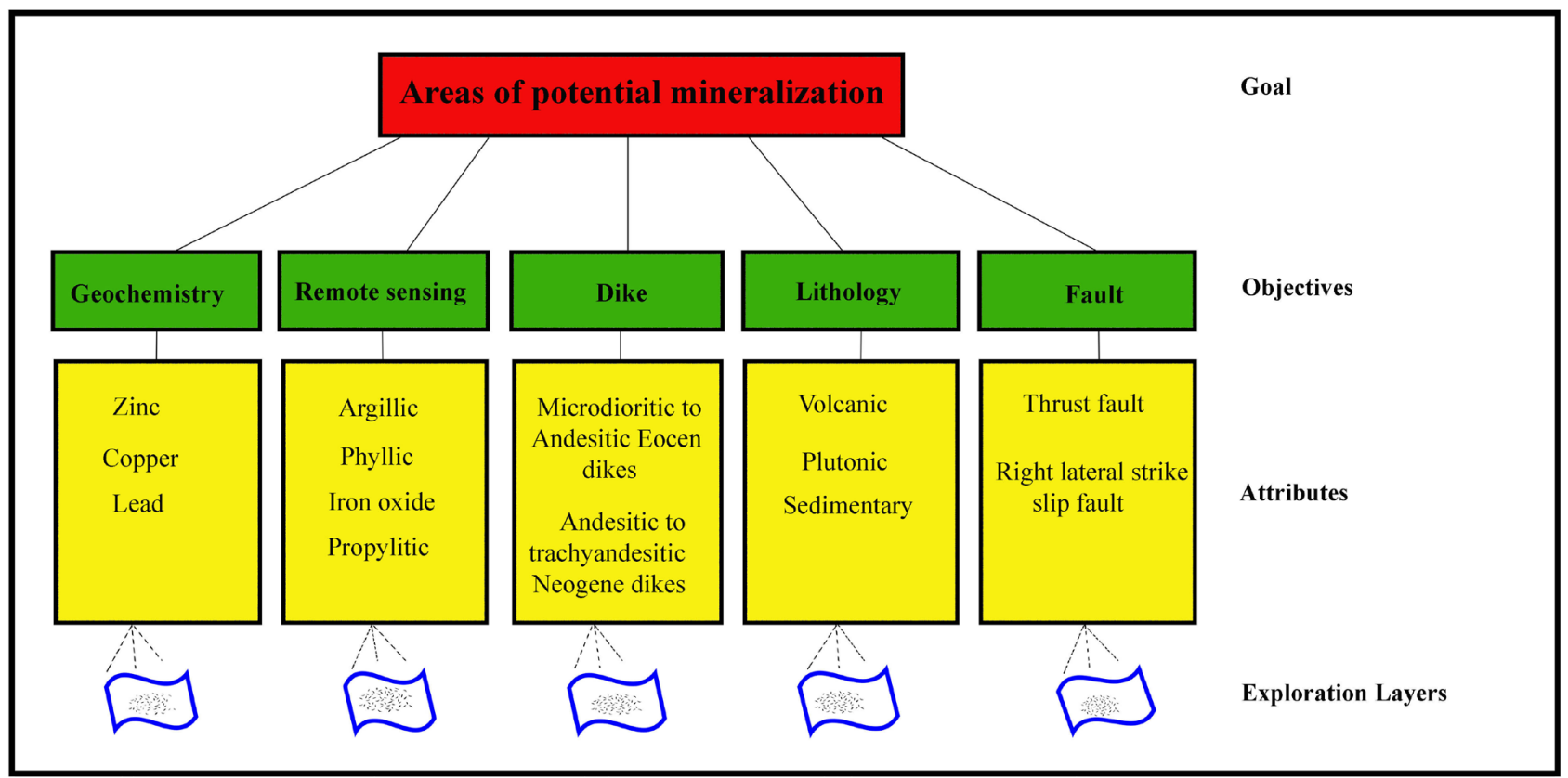

Figure 13. Hierarchical diagram of exploration layers in the area under study.

Table 4. Scale for pair-wise comparisons [48].

\begin{tabular}{cc}
\hline & Scales for pairwise comparisons \\
\hline Intensity of importance & Verbal judgment of preference \\
\hline 1 & Equal importance \\
3 & Moderate importance \\
5 & Strong importance \\
7 & Very strong importance \\
9 & Extreme importance \\
$2,4,6,8$ & Intermediate values between adjacent scale values \\
\hline
\end{tabular}

Note: Adapted from Saaty (1980).

Table 5. Pairwise comparison matrix of the level of objectives and calculated weights.

\begin{tabular}{ccccccc}
\hline & Fault & Lithology & Dyke & Alteration & Geochemistry & AHP weight \\
\hline Fault & 1 & & & & & 0.4918 \\
Lithology & $1 / 3$ & 1 & & & & 0.2689 \\
Dyke & $1 / 4$ & $1 / 3$ & 1 & & 0.1281 \\
Alteration & $1 / 7$ & $1 / 5$ & $1 / 3$ & 1 & & 0.0689 \\
Geochemistry & $1 / 7$ & $1 / 6$ & $1 / 3$ & $1 / 3$ & 1 & 0.0424 \\
\hline
\end{tabular}

\subsection{The Ordered Weighted Averaging (OWA)}

The OWA prepares a proper status of AND, Average and OR degree [49] [50] [51] (Figure 14).

\subsection{The AHP-OWA Model}

To identify the most suitable area in the present research, three outcomes have 
been generated by AHP-OWA procedures at AND, OR, and Average for achieving the favorable areas (Figure 15).

WLC

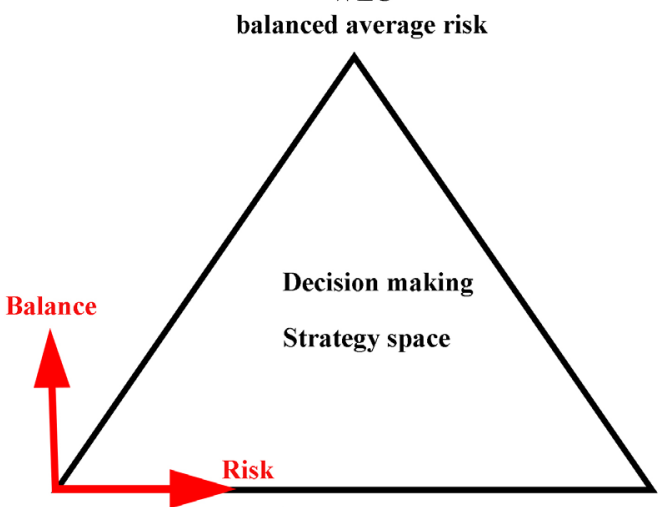

Without risk and balance (AND)

With risk and balance (OR)

Figure 14. Decision making strategy space in OWA method [52].

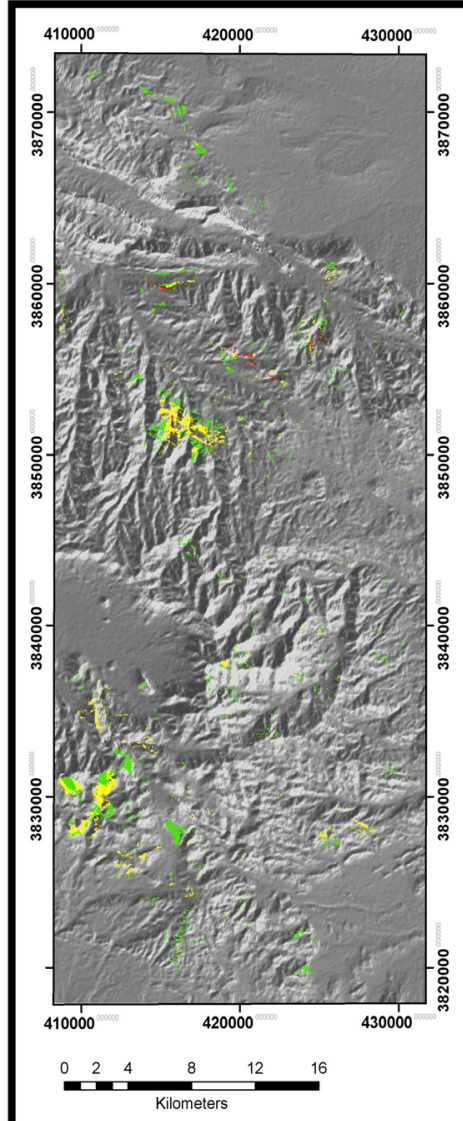

Mineral Prospectivity Priority AHP_OWA_Andness

First class

Second class

Third class

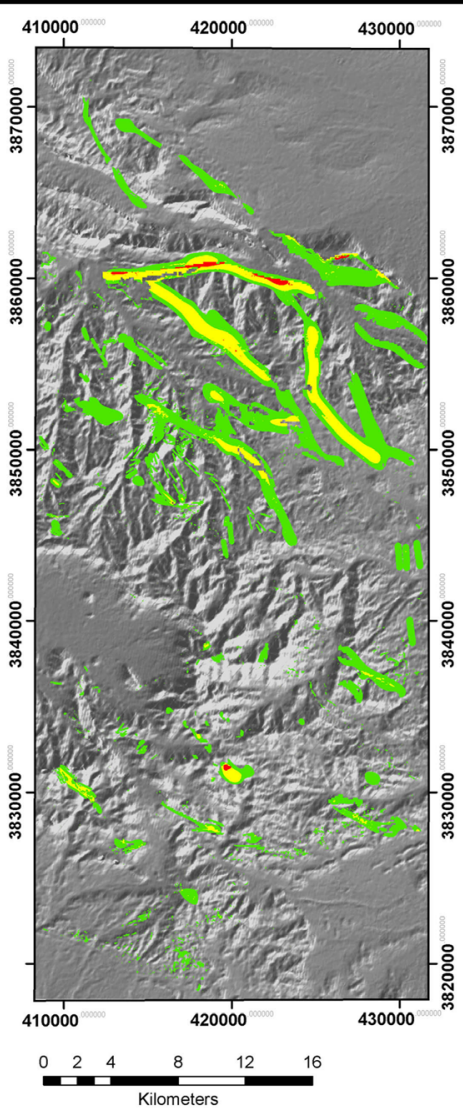

Mineral Prospectivity Priority AHP_OWA_Average

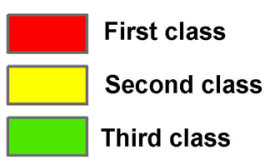

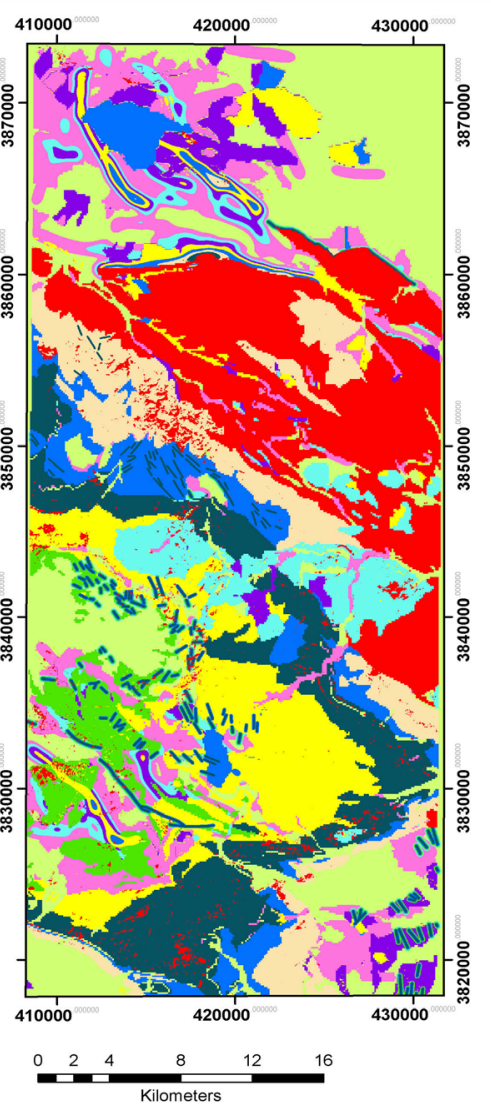

Mineral Prospectivity Priority AHP_OWA_ORness

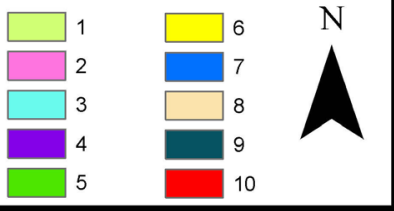

Figure 15. Favorable area maps which have been generated by AHP-OWA procedures in the area under study. 


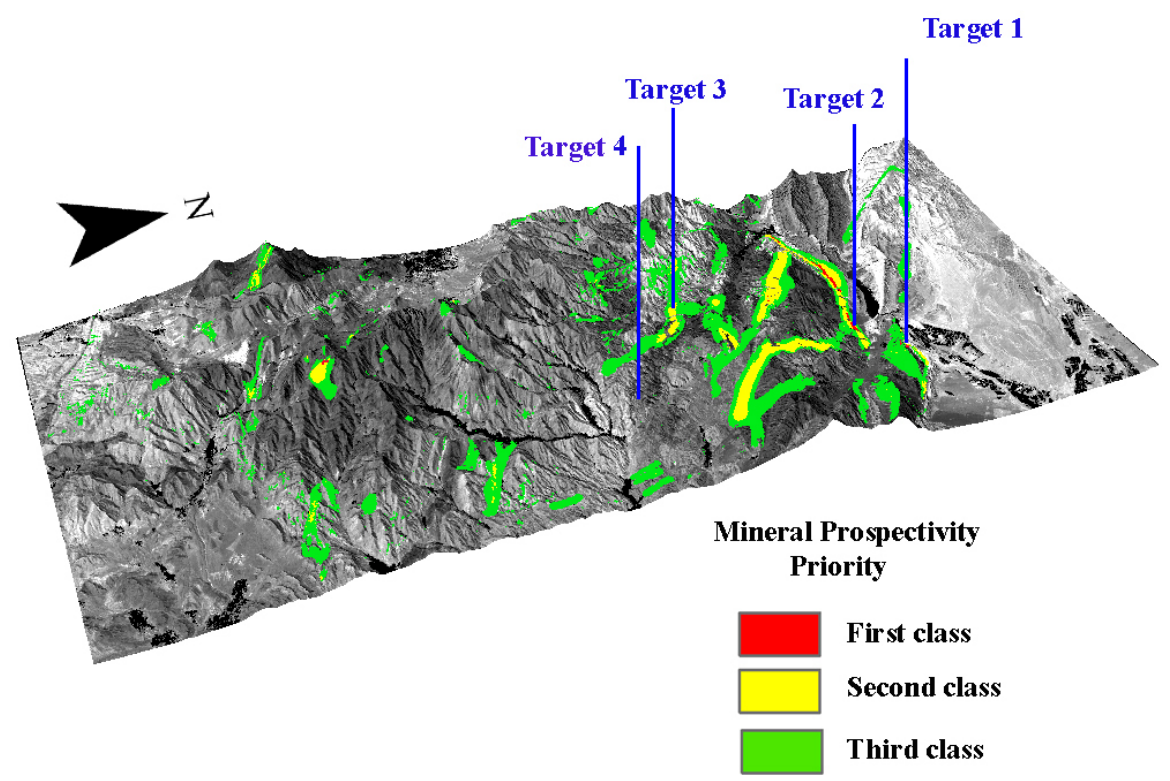

Figure 16. Targets in the area under study.

\section{Field Checking}

The accuracy of the results from AHP-OWA (Average) model was verified by selecting four accessible locations in the area under study (Figure 16).

\subsection{Target 1}

This area is located along a thrust fault $\left(50^{\circ} 10^{\prime} 38^{\prime \prime} \mathrm{E}, 34^{\circ} 53^{\prime} 08^{\prime \prime} \mathrm{N}\right)$ that placed older rocks (Eocene Volcanic Rocks) over younger Oligo-Miocene sedimentary rocks. Argillic, propylitic, and iron oxide alterations affected the rocks. Copper mineralization (malachite) was observed in a barite vein that is perpendicular to the thrust fault trend. The Zn-bearing minerals were detected with Zinc-Zap, which reacts with Zn-bearing minerals to form bright scarlet stains [53], while Fe sulfide minerals, primarily pyrite, cause a dark blue color [54] and other minerals do not react with the zap. In this site, testing the barite vein with this zap gave blue reaction paint, shows the presence of Fe-subfield minerals, and a red reaction color, and indicates the presence of Zn-bearing minerals (Photo 1).

\subsection{Target 2}

This area is located along the fault between Oligo-Miocene sedimentary rocks and Eocene andesitic rocks $\left(50^{\circ} 09^{\prime} 30^{\prime \prime} \mathrm{E}, 34^{\circ} 52^{\prime} 37^{\prime \prime} \mathrm{N}\right)$. Propylitic and iron oxide alterations have been seen in this area. The barite veins with copper mineralization (malachite) have occurred in volcanic rocks. In this site, barite veins tested with Zinc-zap gave a blue reaction color, indicating the presence of Fe-subfield minerals (Photo 2).

\subsection{Target 3}

This site is located in $50^{\circ} 04^{\prime} 51^{\prime \prime} \mathrm{E}, 34^{\circ} 48^{\prime} 27^{\prime \prime} \mathrm{N}$. The most important observations here are that numerous Eocene dioritic dikes, ranging in width from 1 to about 3 
meter, have intruded into the Eocene volcanic rocks. Argillic alteration has affected a wider area around Eocene dikes. Field checking revealed that mineralization has not occurred in this site (Photo 3 ).

\subsection{Target 4}

The last site for checking was located in $50^{\circ} 12^{\prime} 25^{\prime \prime} \mathrm{E}, 34^{\circ} 44^{\prime} 06^{\prime \prime} \mathrm{N}$. In this site, in-

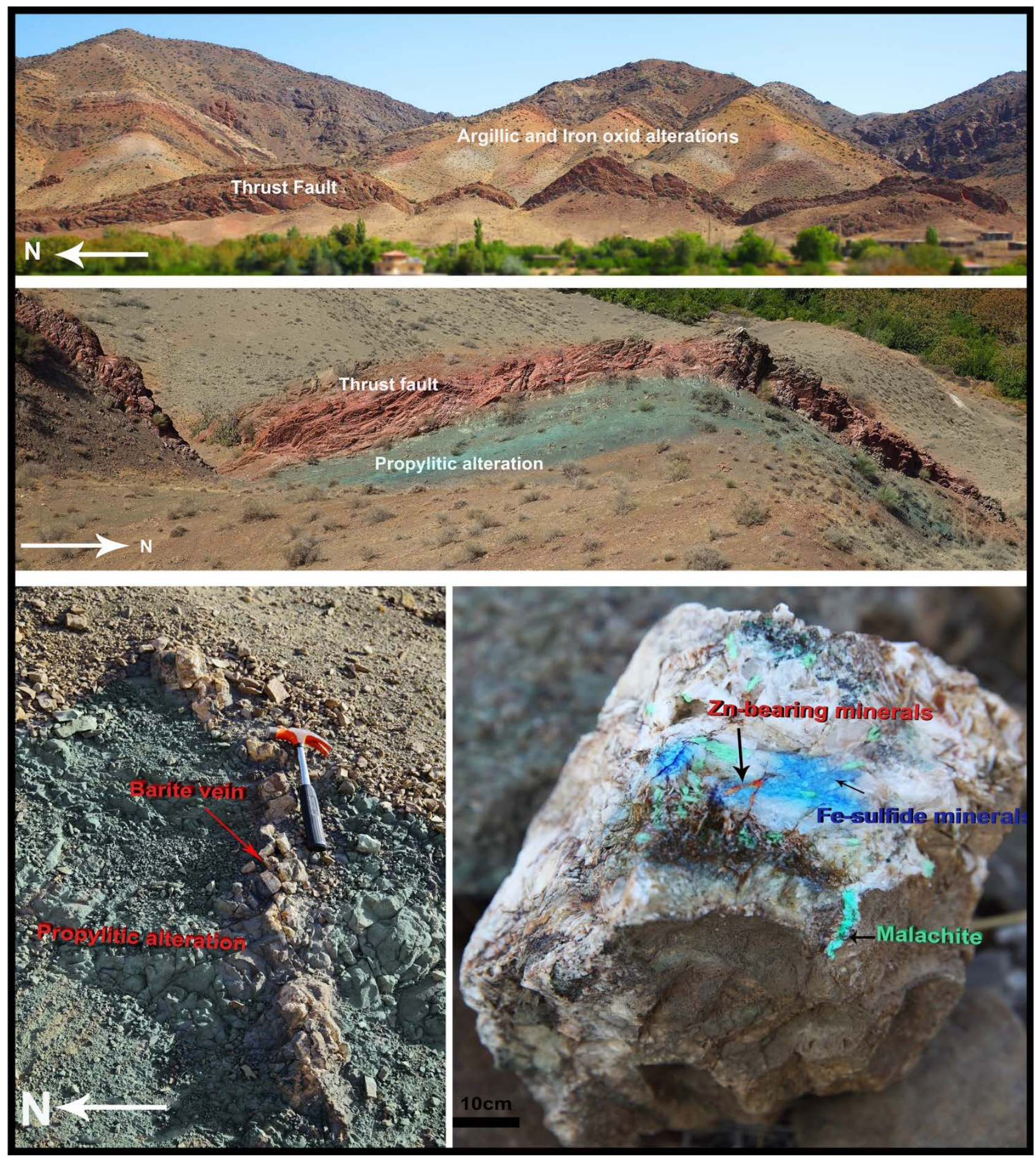

Photo 1 . The observations of the target 1 in the area under study. 


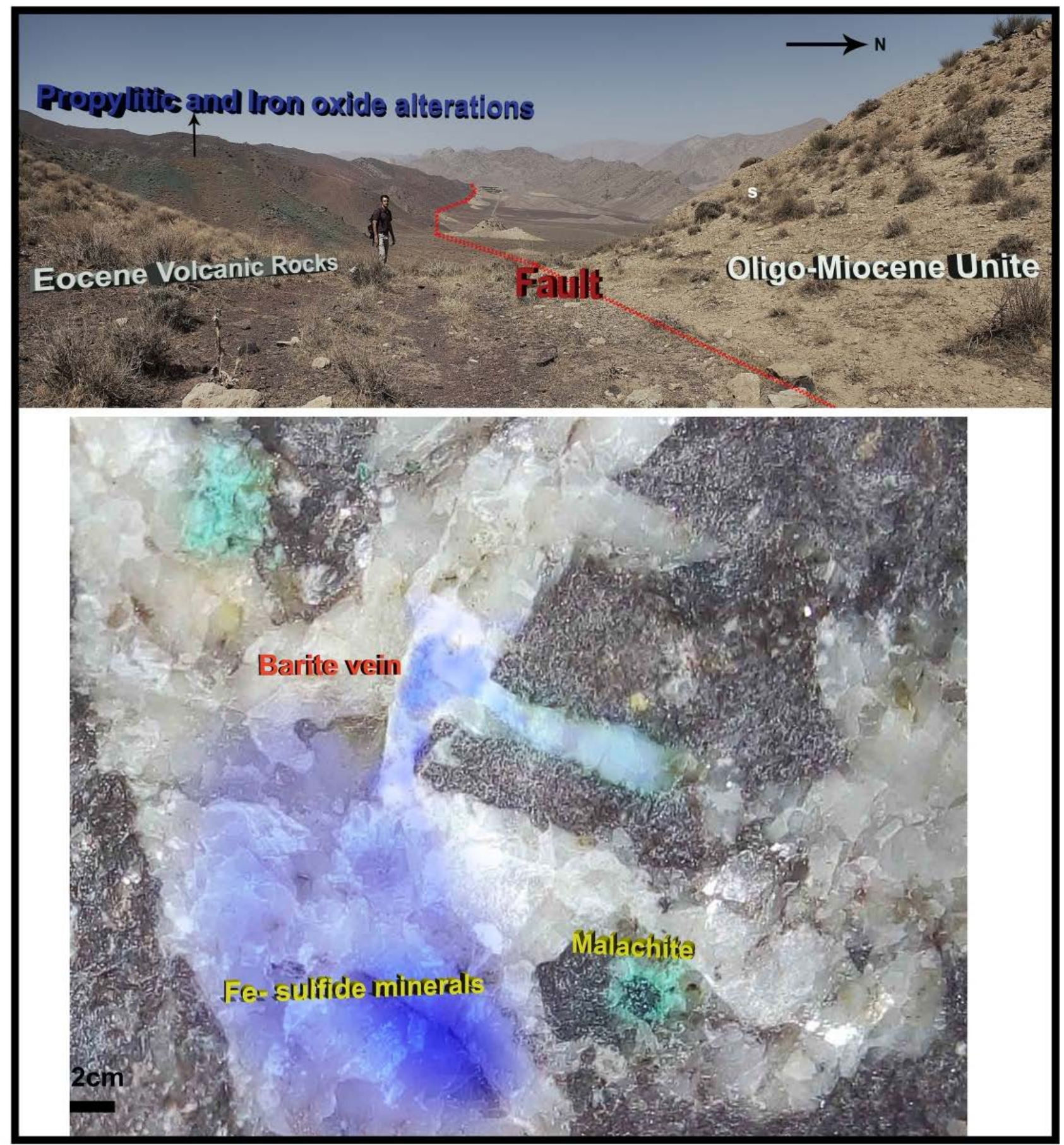

Photo 2 . The observations of the target 2 in the area under study

trusive igneous rock (g) (tonalite-granodiorite) has intruded into the Eocene volcanic rocks. Evidence of extensive hydrothermal alteration and mineralization has not been observed in this outcrop. Pyrite has altered to iron oxide minerals in these rocks (Photo 4 ).

\section{Results}

The area under study is located in Urmia-Dokhtar structural zone of Iran. The 


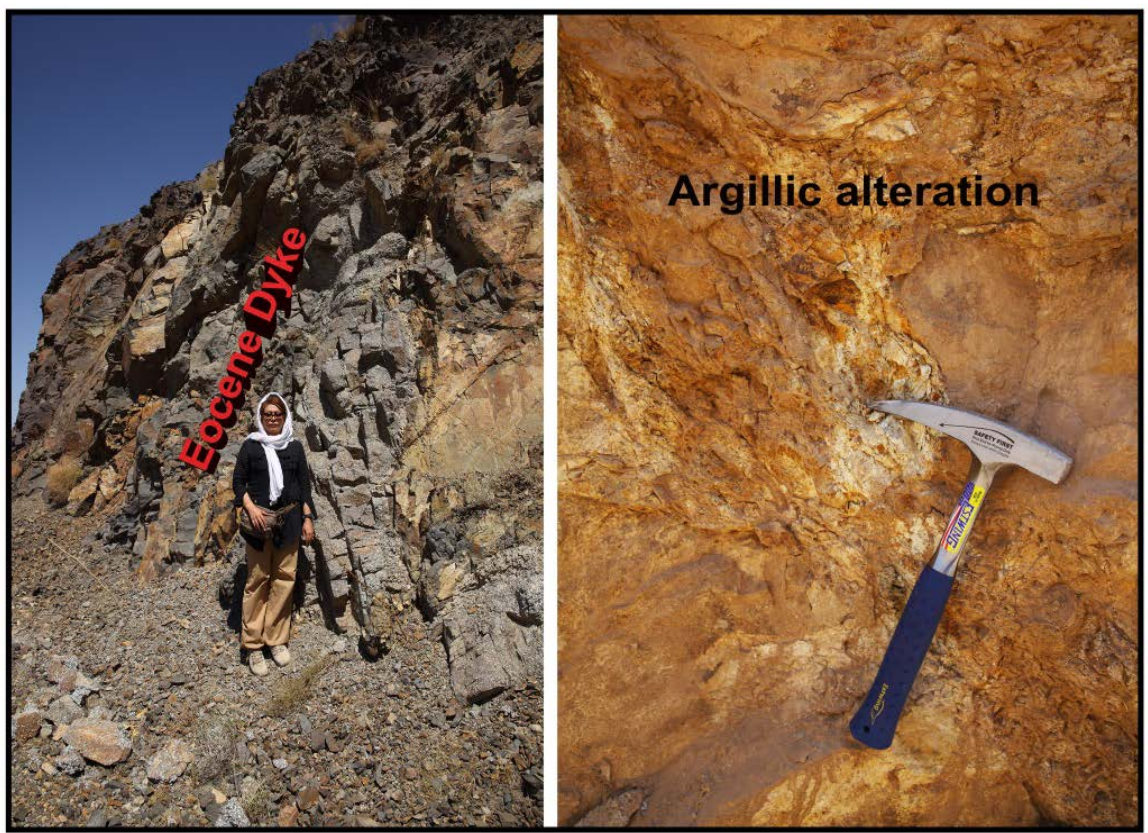

Photo 3. The observations of the target 3 in the area under study.

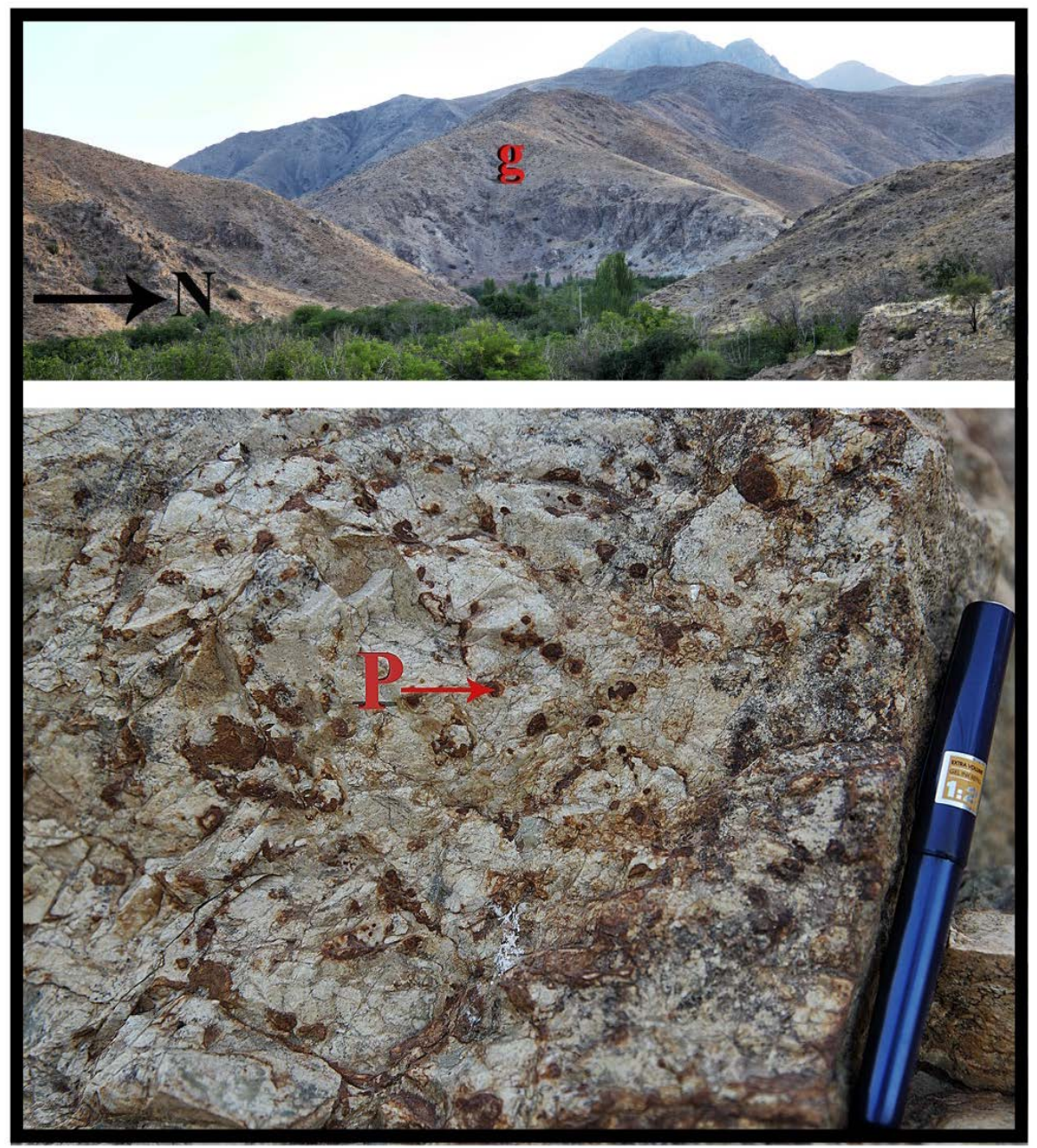

Photo 4 . The observations of the target 4 in the area under study. 
Urumieh-Dokhtar magmatic belt (UDMB) is the main copper-bearing region in Iran. We have obtained the following results from this research.

\subsection{Chemical Analysis Results}

The chemical analysis of stream sediment samples in the area under study shows that:

- A strong correlation exists between $\mathrm{Pb}$ and $\mathrm{Ba}, \mathrm{Pb}$ and $\mathrm{Ag}$, and $\mathrm{Pb}$ and $\mathrm{As}$, but no statistically significant correlation is evident between $\mathrm{Pb}$ and $\mathrm{Zn}$.

- Factor analysis suggests that the element community can be related to parent rocks or mineralization of copper, zinc, and lead.

\subsection{Remote Sensing Results}

We mapped the distribution of hydrothermal alterations using ASTER data and obtained the following results in the area under study:

- The main alteration types in the region are phyllic, argillic, propylitic, and iron oxide.

- The development of hydrothermal alteration halos occurred around the faults and dikes.

- The integration of the RBD, MNF, and LS-Fit algorithms create complete and accurate information regarding the distribution of hydrothermal alteration zones in the region.

\subsection{Integration of the Layer Results}

When several themes were combined using the AHP-OWA technique, the following results were achieved for the area under study:

- Faults have played a significant role in mineralization in this area.

- No mineralization has occurred in intrusive rocks.

- Based on the final combined models generated by AHP-OWA, the "Average" model was considered for field checking.

\subsection{Field Checking Results}

Limited field checking was done to verify the validity of the results in this study. Based on field observation, the following results were obtained:

- The results from remote sensing study have been verified by direct observation.

- Copper and zinc mineralization have been discovered in the area under study.

- Mineralization has not been found in the contact of dikes and country rocks.

- Mineralization has not been found inside and contact of intrusion.

- Field checking confirmed the accuracy of results from this study.

\section{Conclusion}

To produce the mineral exploration map for copper, zinc, and lead mineralization, we used fuzzy AHP and OWA technique on the basis of evidence layers de- 
rived from geological, geochemical, and remotely sensed data. Field anomaly checking demonstrates that the results of the fuzzy AHP-OWA model are reliable for the predicted areas of mineral potential.

\section{References}

[1] Shalchi, P. and Advay, M. (2014) Stream Sediment Geochemical Exploration for Gold in Hashatjin. International Journal of Basic Sciences \& Applied Research, 3, 644-651.

[2] Khan, J.A. and Alnuweiri, H.A. (2004) A Fuzzy Constraint-Based Routing Algorithm for Traffic Engineering. IEEE Communications Society Globecom, 13661372 .

[3] Jafarirad, A.R. (2009) Modeling of Conceptual and Empirical Geospatial Datasets for Mineral Prospecting Mapping. PhD Dissertation, Clausthal University of Technology, Clausthal-Zellerfeld.

[4] McKay, G. and Harris, J.R. (2016) Comparison of the Data-Driven Random Forests Model and a Knowledge-Driven Method for Mineral Prospectivity Mapping: A Case Study for Gold Deposits around the Huritz Group and Nueltin Suite, Nunavut, Canada. Natural Resources Research, 25, 125-143. https://doi.org/10.1007/s11053-015-9274-Z

[5] Jafarirad, A.R. and Busch, W. (2011) Porphyry Copper Mineral Prospectivity Mapping Using Interval Valued Fuzzy Sets Topsis Method in Central Iran. Journal of Geographic Information System, 3, 312-317. https://doi.org/10.4236/jgis.2011.34028

[6] Magalhães, L.A. and Souza Filho, C.R. (2012) Targeting of Gold Deposits in Amazonian Exploration Frontiers Using Knowledge and Data-Driven Spatial Modeling of Geophysical, Geochemical, and Geological Data. Survey in Geophysics, 33, 211241. https://doi.org/10.1007/s10712-011-9151-1

[7] Ford, A., Miller, J.M. and Mol, A.G. (2016) A Comparative Analysis of Weights of Evidence, Evidential Belief Functions, and Fuzzy Logic for Mineral Potential Mapping Using Incomplete Data at the Scale of Investigation. Natural Resources Research, 25, 19-33.

[8] Geranian, H., Tabatabaei, S.H., Asadi, H.H. and Carranza, E.J.M. (2016) Application of Discriminant Analysis and Support Vector Machine in Mapping Gold Potential Areas for Further Drilling in the Sari-Gunay Gold Deposit, NW Iran. Natural Resources Research, 25, 145-159.

[9] Nykänen, V., Groves, D.L., Ojala, V.J., Eilu, P. and Gardoll, S.J. (2008) Reconnaissance-Scale Conceptual Fuzzy-Logic Prospectivity Modelling for Iron Oxide Copper Gold Deposits in the Northern Fennoscandian Shield, Finland. Australian Journal of Earth Sciences, 55, 25-38. https://doi.org/10.1080/08120090701581372

[10] Carranza, E.J.M. (2008) Geochemical Anomaly and Mineral Prospectivity Mapping in GIS. Elsevier, Amsterdam.

[11] Malczewski, J. (1999) Gis and Multicriteria Decision Analysis. Science, 100, 392.

[12] Meng, Y., Malczewski, J. and Boroushaki, S. (2011) A Gis-Based Multicriteria Decision Analysis Approach for Mapping Accessibility Patterns of Housing Development Sites: A Case Study in Canmore, Alberta. Journal of Geographic Information System, 3, 50-61. https://doi.org/10.4236/jgis.2011.31004

[13] Rahnama, M.R., Aghajani, H. and Fattahi, M. (2012) Integrating Ordered Weighted Average Techniques with Geographic Information Systems for Landfill Site Selection (Case study: Metropolis of Mashhad). Geography and Environmental Hazards, 3, 13-15. 
[14] Alavi, M. (1994) Tectonics of Zagros Orogenic Belt of Iran, New Data and Interpretation. Tectonophysics, 229, 211-238. https://doi.org/10.1016/0040-1951(94)90030-2

[15] Waterman, G.C. and Hamilton, R.L. (1975) The Sar-Cheshmeh Porphyry Copper Deposit. Economic Geology, 70, 568-576.

[16] Shahabpour, J. (1982) Aspects of Alteration and Mineralization at the Sar-Cheshmeh Copper-Molybdenum Deposit, Kerman, Iran. University of Leeds, Leeds.

[17] Hezarkhani, A. (2006) Hydrothermal Evolution of the Sar-Cheshmeh Porphyry CuMo Deposit, Iran, Evidence from Fluid Inclusions. Journal of Asian Earth Sciences, 28, 409-422. https://doi.org/10.1016/j.jseaes.2005.11.003

[18] Hezarkhani, A., Williams-Jones, A.E. and Gammons, C.H. (1999) Factors Controlling Copper Solubility and Chalcopyrite Deposition in the Sungun Porphyry Copper Deposit. Mineralium Deposita, 34, 770-783.

[19] Hassanzadeh, J. (1993) Metallogenic and Tectono-Magmatic Events in the SE Sector of the Cenozoic Active Continental Margin of Iran. University of California, Oakland.

[20] Boomeri, M., Nakashima, K. and Lentz, D.R. (2009) The Miduk Porphyry Cu Deposit, Kerman, Iran. A Geochemical Analysis of the Potassic Zone Including Halogen Element Systematics Related to $\mathrm{Cu}$ Mineralization Processes. Journal of Geochemical Exploration, 103, 17-29. https://doi.org/10.1016/j.gexplo.2009.05.003

[21] Zarasvandi, A., Liaghat, S. and Zentilli, M. (2005) Geology of the Darreh-Zerreshk and Ali-Abad Porphyry Copper Deposits, Central Iran. International Geology Review, 47, 620-646. https://doi.org/10.2747/0020-6814.47.6.620

[22] Baranpurian, N., Emami, M.H., Vossoughi Abedini, M. and Dabiri, R. (2014) Mineral Chemistry and Thermobarometry of the Upper Eocene Volcanic Rocks in NE Tafresh, Iran. Open Journal of Geology, 4, 612-621.

[23] El-Makky, A.M. (2011) Statistical Analyses of La, Ce, Nd, Y, Nb, Ti, P, and Zr in Bedrocks and Their Significance in Geochemical Exploration at the Um Garayat Gold Mine Area, EASTERn Desert, Egypt. Natural Resources Research, 20, 157-176. https://doi.org/10.1007/s11053-011-9144-2

[24] Howarth, R.J. (2013) Statistics and Data Analysis in Geochemical Prospecting. Elsevier, Amsterdam.

[25] Beus, A.A. and Grigorian, S.V. (1977) Geochemical Exploration Methods for Mineral Deposits. Applied Publishing, Wilmette.

[26] Ciampalini, A., Garfagnoli, F., Del Ventisette, C. and Moretti, S. (2013) Potential Use of Remote Sensing Techniques for Exploration of Iron Deposits in Western Sahara and Southwest of Algeria. Natural Resources Research, 22, 179-190. https://doi.org/10.1007/s11053-013-9209-5

[27] Van Ruitenbeek, F.J.A., Cudahy, T.J., Van Der Meer, F.D. and Hale, M. (2012) Characterization of the Hydrothermal Systems Associated with Archean VMSMineralization at Panorama, Western Australia, Using Hyperspectral, Geochemical and Geothermometric Data. Ore Geology Reviews, 45, 33-46.

[28] Haroni, H.A. and Lavafan, A. (2007) Integrated Analysis of ASTER and Landsat ETM Data to Map Exploration Tar-Gets in the Muteh Gold-Mining Area, Iran. 5 th International Symposium on Spatial Data Quality, Enschede, 13-15 June 2007, 104-110.

[29] Azizi, H., Tarverdi, M.A. and Akbarpour, A. (2010) Extraction of Hydrothermal Alterations from ASTER SWIR Data from East Zanjan, Northern Iran. Advances in Space Research, 46, 99-109. https://doi.org/10.1016/j.asr.2010.03.014 
[30] Shariari, H., Ranjbar, H. and Honarmand, M. (2013) Image Segmentation for Hydrothermal Alteration Mapping Using PCA and Concentration-Area Fractal Model. Natural Resources Research, 22, 191-206. https://doi.org/10.1007/s11053-013-9211-y

[31] Hassani Pak, A.A. (2010) Principles of Geochemical Exploration. Tehran University Press, Tehran.

[32] Sabins, F.F. (1999) Remote Sensing for Mineral Exploration. Ore Geology Reviews, 14, 157-183.

[33] Beiranvnd Pour, A., Hashim, M. and Marghany, M. (2010) Characterization of ASTER Data for Mineral Exploration. CD Proceedings MRSS 6 th international Remote Sensing \& GIS Conference and Exhibition, Kuala Lumpur, 28-29 April 2010, 233-242.

[34] Yamaguchi, Y.I., Fujisada, H., Kudoh, M., Kawakami, T., Tsu, H., Kahle, A.B. and Pniel, M. (1999) ASTER Instrument Characterization and Operation Scenario. Advances in Space Research, 23, 1415-1424. https://doi.org/10.1016/S0273-1177(99)00293-8

[35] Yamaguchi, Y., Kahle, A.B., Kawakami, T. and Paniel, M. (1998) Overview of the Advanced Spaceborne Thermal Emission and Reflection Radiometer (ASTER). IEEE Transaction on Geoscience and Remote Sensing, 36, 1062-1071.

[36] Yamaguchi, Y. and Naito, C. (2003) Spectral Indices for Lithologic Discrimination and Mapping by Using the ASTER SWIR Bands. International Journal of Remote Sensing, 24, 4311-4323. https://doi.org/10.1080/01431160110070320

[37] Crowley, J.K., Brickey, D.W. and Rowan, L.C. (1989) Airborne Imaging Spectrometer Data of the Ruby Mountains. Montana: Mineral Discrimination Using Relative Absorption-Band-Depth Images. Remote Sensing of Environment, 29, 121-134.

[38] Li, S., Chen, J. and Baltsavias, E. (2008) Advances in Photogrammetry, Remote Sensing and Spatial Information Sciences. CRC Press, Boca Raton.

[39] Ramachandran, B., Justice, C.O. and Abrams, M.J. (2010) Land Remote Sensing and Global Environmental Change: Nasa's Earth Observing System and the Science of ASTER and MODIS. Springer Science \& Business Media, Berlin.

[40] Li, Q., Zhang, B., Lu, L. and Lin, Q. (2014) Hydrothermal Alteration Mapping Using ASTER Data in Baogutu Porphyry Deposit, China. 35th International Symposium on Remote Sensing of Environment, IOP Conference Series: Earth and Environmental Science, Beijing, 22-26 April 2013, 17.

[41] Boardman, J.W., Kruse, F.A. and Green, R.O. (1995) Mapping Target Signatures via Partial Unmixing of AVIRIS Data. Summaries Proceedings of the Fifth JPL Airborne Earth Science Workshop, Pasadena, 23-26 January 1995, 95-101.

[42] Beiranvnd Pour, A., Hashim, M. and Marghany, M. (2011) Using Spectral Mapping Techniques on Short Wave Infrared Bands of ASTER Remote Sensing Data for Alteration Mineral Mapping in SE Iran International Journal of the Physical Sciences, 6, 917-929.

[43] Papadaki, S.E., Mertikas, S.P. and Sarris, A. (2011) Identification of Lineaments with Possible Structural Origin Using ASTER Images and Dem Derive Products in Western Crete, Greece. European Remote Sensing Laboratories, 10, 9-26.

[44] Sarp, G. (2005) Lineament Analysis from Satellite Images, North-West of Ankara. Middle East Technical University, Ankara.

[45] Sadeghi, B., Khalajmasoumi, M., Afzal, P. and Moarefvand, P. (2014) Discrimination of Iron High Potential Zones at the Zaghia Iron Ore Deposit, Bafq, Using Index Overlay GIS Method Iranian Journal of Earth Sciences, 6, 91-98. 
[46] Carranza, E.J.M. and Hale, M. (1997) A Catchment Basin Approach to the Analysis of Geochemical and Geological Data from Albay Province, Philippines. Journal of Geochemical Exploration, 60, 157-171. https://doi.org/10.1016/S0375-6742(97)00032-0

[47] Boroushaki, S. and Malczewski, J. (2008) Implementing an Extension of the Analytical Hierarchy Process Using Ordered Weighted Averaging Operators with Fuzzy Quantifiers in ArcGIS. Computers \& Geosciences, 34, 399-410. https://doi.org/10.1016/j.cageo.2007.04.003

[48] Saaty, T. and Vargas, L.G. (1991) Prediction, Projection and Forecasting. Kluwer Academic Publisher, Boston. https://doi.org/10.1007/978-94-015-7952-0

[49] Yager, R.R. (1988) On Ordered Weighted Averaging Aggregation Operators in Multi-Criteria Decision Making. IEEE Transactions on Systems, Man and Cybernetics, 18, 183-190. https://doi.org/10.1109/21.87068

[50] Meng, Y., Malczewski, J. and Boroushaki, S. (2011) A Gis-Based Multicriteria Decision Analysis Approach for Mapping Accessibility Patterns of Housing Development Sites: A Case Study in Canmore, Alberta. Journal of Geographic Information System 3, 50-61. https://doi.org/10.4236/jgis.2011.31004

[51] Jiang, H. and Eastman, R.J. (2000) Application of Fuzzy Measures in Multi-Criteria Evaluation in GIS. International Journal of Geographical Information Science, 14, 173-184. https://doi.org/10.1080/136588100240903

[52] Eastman, J.R. (1997) IDRISI for Windows, Version 20: Tutorial Exercises. Clark University, Worcester, MA.

[53] Németh, N., Kasó, A. and Földessy, J. (2012) Sphalerite Indications in the Aggtelek Mts. Geosciences and Engineering, 1, 255-260.

[54] Hitzman, M.W., Reynolds, N.A., Sangster, D.F., Allen, C.R. and Carman, C.E. (2003) Classification, Genesis, and Exploration Guides for Nonsulfide Zinc Deposits. Economic Geology, 98, 685-714. https://doi.org/10.2113/gsecongeo.98.4.685

Submit or recommend next manuscript to SCIRP and we will provide best service for you:

Accepting pre-submission inquiries through Email, Facebook, LinkedIn, Twitter, etc. A wide selection of journals (inclusive of 9 subjects, more than 200 journals)

Providing 24-hour high-quality service

User-friendly online submission system

Fair and swift peer-review system

Efficient typesetting and proofreading procedure

Display of the result of downloads and visits, as well as the number of cited articles

Maximum dissemination of your research work

Submit your manuscript at: http://papersubmission.scirp.org/

Or contact ojg@scirp.org 